\title{
Factors for Implementing Green Supply Chain Management in the Construction Industry
}

\author{
Mochamad Agung Wibowo ${ }^{1}$ (D), Naniek Utami Handayani2 ${ }^{2}$ (D), Anita Mustikasari2 ${ }^{2}$ iD \\ ${ }^{1}$ Department of Civil Engineering, Faculty of Engineering, Diponegoro University (Indonesia) \\ ${ }^{2}$ Department of Industrial Engineering, Faculty of Engineering, Diponegoro University (Indonesia) \\ agung.wibowo@ft.undip.ac.id,naniekh@ft.undip.ac.id,anitamustikasari91@gmail.com
}

Received: April 2018

Accepted: June 2018

\section{Abstract:}

Purpose: The objectives of this study are to elaborate on the concepts, dimensions and elements of green supply chain management (GSCM) and develop a framework of GSCM implementation for the construction industry

Design/methodology/approach: This paper presents the findings from a study where experts were asked to contribute their opinions related to GSCM in the construction industry. To develop the model, the Delphi method was used. The objective of this method is to achieve the most reliable consensus in a group of experts

Findings: The research result is a developed framework for GSCM in the construction industry comprising five concepts, 22 dimensions, and 82 elements.

Research limitations/implications: The limitation of this research is that its output was the discovered elements, but it did not cover the implementation of this model in construction projects, so some elements may be missing.

Practical implications: The output of the research could give new perspective to manage the construction project based on Green Supply Chain Method.

Social implications: The stakeholder of the construction project has to learn with this concept (Green Supply Chain) in order to improve construction's project performance.

Originality/value: The originality of this research is that it is a new theme in the area of the construction supply chain. Previous research merely considered the concept of GSCM in construction. Therefore, this research develops an assessment model for performance indicators of GSCM implementation in construction projects.

Keywords: green supply chain management, construction industry, construction waste, project life cycle

\section{To cite this article:}

Wibowo, M.A., Handayani, N.U., \& Mustikasari, A. (2018). Factors for Implementing Green Supply Chain Management in the Construction Industry Journal of Industrial Engineering and Management, 11(4), 651-679. https://doi.org/10.3926/jiem.2637 


\section{Introduction}

Sustainable growth has been featured around the world as a fundamental rule for building up and overseeing authoritative strategies, since the 2005 announcement of the Kyoto Protocol (Wang, Chen, Lee \& Tsai, 2013). Resource constraints, rising fuel and energy prices causing irreparable damage, increasing concerns over carbon emissions, resource scarcity, climate change and waste generation have become business environment challenges that must be faced (Dadhich, Genovese, Kumar \& Acquaye, 2015).

Observation from the stakeholders' points of view, including those of the contractor (Qi, Shen, Zeng \& Jorge, 2010) and developer (Abidin, 2010), only covers a small number of supply chain issues that are successfully addressed. While governments, practitioners and researchers have made efforts to deal with the negative factors associated with this field, most attempts have been disjointed and fragmented. The issues include green transportation (BRE, 2003), purchasing (Varnäs, Balfors \& Faith-Ell, 2009) and green practices (Qi et al., 2010).

Due to the impact of a lack of comprehensive understanding, policymakers and practitioners would potentially be incorrect in their focus, addressing the wrong issues and omitting factors that have a greater influence. The important delivery chain stakeholders, such as the developers, consultants, suppliers and contractors, at the myriad stages of the supply chain must achieve the net greening of a production task to attain their opposing goals (UN Global Compact, 2010; UNEP-SBCI, 2016). Presently, only a few studies have focussed on the construction sector, conducting systematic and comprehensive green studies on sundry supply chain stages and stakeholders. A green supply chain management (GSCM) approach to solving the relevant problems can be studied in terms of the following elements:

- Stakeholders' implementation of green practice;

- Stakeholders' motivation for applying such methods;

- Stakeholders' barriers in the implementation of these practices; and

- The implications for overall performance.

GSCM-associated investigations have given advantages to the manufacturing and automotive sectors (Malviya \& Kant, 2015); for greening the construction sector, a comprehensive GSCM-orientated study is required to provide complete awareness of the various essential conditions. This motivated research seeking to develop and validate a multidimensional GSCM framework for the construction sector that would embrace all the important supply chain stages and account for the roles of the numerous stakeholders and consider the framework to comprehensively establish the GSCM factors of the construction sector. The purposes of this GSCM study on the construction sector are as follows:

- To develop the relevant GSCM constructs;

- To develop a comprehensive GSCM assessment framework that captures the interrelationships between the constructs; and

- $\quad$ To test and validate the framework.

GSCM has important purposes related to environmental performance, such as risk control, meeting marketplace expectations, achieving good commercial enterprise performance and complying with regulations (Zhu, Tian \& Sarkis, 2012). Sector industries have begun to include GSCM implementation in customers' needs in response to governmental environmental regulation, and this may result in environmentally sustainable practices (Green Jr., Zelbst, Meacham \& Bhadauria, 2012).

Researchers have studied environmental concerns since the 1990s and encouraged more responsible, comprehensive practices in supply chain management (Guang-Shi, Lenny-Koh, Baldwin \& Cucchiella, 2012). Empirical GSCM research and theory has explored the effect, implementation and result of GSCM practices, such as cleaner production, eco-design, reverse logistics (RL), green purchasing, financial utilisation, environmental performance and operational measurement (Wu, Dunn \& Forman, 2012). Studies on GSCM have been 
implemented at various areas (Green Jr. et al., 2012; Ojo, Mbohwa \& Akinlabi, 2014; Wu et al., 2012; Xiao, 2006; Zhu et al., 2012).

GSCM, which seeks to incorporate environmental concerns into SCM, has emerged as a holistic environmental management approach (Malviya \& Kant, 2015); as the environmental effects of a product/project typically occur at all its lifecycle stages, a supply chain-wide focus makes sense (Hervani, Helms \& Sarkis, 2005; Wu, Tseng \& Vy, 2011). GSCM emphasises efficient, effective and extensive implementation of green practices, or activities/initiatives to reduce the environmental footprint (Awaysheh \& Klassen, 2010; Perotti, Zorzini, Cagno \& Micheli, 2012), which in turn, depends on the ability to manage 'antecedents', that is, the drivers and barriers that affect the implementation of green practices (Drohomeretski, Gouvea da Costa \& Pinheiro de Lima, 2014; Luthra, Garg \& Haleem, 2015; Walker \& Jones, 2012), and 'consequences', that is, the effects that green practices have on environmental and short- and long-term financial performance (Green Jr. et al., 2012; Rao \& Holt, 2005). Importantly, this understanding of green practices and associated 'antecedents' and 'consequences' has to be at the level of individual stakeholders (in a sector), so that their conflicting interests can be managed and a unified, sectorwide greening is possible (Drohomeretski et al., 2014; Gold, Seuring \& Beske, 2010; Hervani et al., 2005). Such a comprehensive (GSCM-oriented) investigation and resulting understanding could be used to green the construction sector. This forms the focus of the present work, where a comprehensive investigation on construction covering green practices' implementation across all critical stages (from initial development of the design to end-of-life demolition and recycling), drivers for and barriers to their implementation and their different performance implications, all at the level of individual stakeholders - developers, architects/consultants, contractors/ subcontractors and material suppliers - is undertaken. Such an investigation has not been previously attempted; the previous research has mainly been fragmented and disjointed, focussing only on specific green practices, such as green purchasing (Varnäs et al., 2009); antecedents for specific green practices, such as drivers for green construction (Qi et al., 2010) and barriers to green purchasing (Sourani, 2011); specific consequences, such as environmental performance (Tam, Tam, Zeng \& Chan, 2006); and specific stakeholders, such as developers (Abidin, 2010) or contractors (Qi et al., 2010).

Based on previous research on the green supply chain in the manufacturing industry, this concept will be applied to the construction sector. The objective of this study is to elaborate the concepts, dimension and elements of GSCM in the construction industry and develop a framework for GSCM implementation in this industry.

\section{Green Supply Chain Management}

\subsection{Supply Chain Management in the Construction Industry}

Currently, construction SCM (CSCM) is achieving rapid growth around the world. In almost all countries, the construction industry plays significant role in managing physical facilities and infrastructure. Construction certainly has a huge indirect effect on other industries through the model of demand and supply. As representative of the manufacturing industries, the construction industry needs materials from other industries to produce buildings or infrastructure. Therefore, the supply and demand model in the construction industry has significantly contributed to economic growth (Bohari, Skitmore, Xia, Teo, Zhang \& Adham, 2015); this model is highly complex, diverse and fragmented, involving a multitude of stakeholders participating in dyadic relationships (Balasubramanian \& Shukla, 2017a). For example, in a construction project like a building project, the number of organisations involved in the supply chain can run into the hundreds. Moreover, the construction supply chain has a reputation for low trust and adversarial trading relations between supply chain stakeholders (Akintoye, McIntosh \& Fitzgerald, 2000; Korczynski, 1996).

The process of construction depends on predesign decisions that consider cost and time as effects (Irizarry, Karan \& Jalaei, 2013). Planning and arranging the amounts of materials required for a project construction site has become a high consideration in CSCM (O’Brien, Formoso, Ruben \& London, 2008). Irizarry et al. (2013) also proposed a framework for CSCM information flows. There are several activities, from design phase to the construction phase, which stakeholders must carry out in the construction supply chain, including predesign decisions, sourcing, logistics (warehousing and transportation), performance management, and monitoring and inspection. 
The developer directs consultants to provide design and any professional management services. In addition, the developer chooses the main contractor that should execute the activities or carry out subcontracting. After completing the project (building), the final performance by consultants is carried out, and then the project it is handed to the developer, ready for implementation. This information and material flow perspective of CSCM clearly verifies that creating of green performance in construction requires all important supply chain stakeholders' involvement.

\subsection{Issues of Sustainability for Supply Chain Management in the Construction Industry \\ 2.2.1. Waste Management}

In the construction industry, waste has been recognised as a primary problem due to its direct effects on the environment and the efficiency of the construction industry. Many studies have shown that there are a lot of extravagant processes during the design and construction phases. Waste is defined as the movement of workers that does not provide added value and is unnecessary in a process (Formoso, Soibelman, De Cesare \& Isatto, 2002). Waste can also be described as any human activity that absorbs a certain amount of resources but does not produce added value, such as errors requiring repair, unwanted production, unnecessary processes or processing, useless movement of labour and waiting for the results of previous activities (Formoso et al., 2002). According to (Ekanayake \& Ofori, 2004), construction waste is defined as a material, other than the material of the earth, that is transported to another place on the project site or used on the project site and does not conform to the specifications of the project because it is damaged, excess and unused/unusable or a production of the construction process that is not according to plan. In construction, waste can be a delay of time, lack of security, reworking, excessive costs, unnecessary travel or transfer, long shipping distances, imprecision in the selection of operation methods or bad management tools and capacity-building measures. In addition, Wibowo has conducted several studies related to construction waste, such as identifying the influence level of the waste in construction management (Wibowo \& Koestalam, 2015).

In the construction process, waste occurs in every phase of the project lifecycle (PLC). Some studies have suggested that the waste needs to be managed from the design phase (Osmani, Glass \& Price, 2008); thus, the architect has a decisive role to play in helping to reduce waste by focussing on designing it out. About one-third of construction waste can essentially arise from design decisions. There are several waste-minimisation measures identified in implementing construction waste management (WM), such as using materials that have reused packing; using refillable, durable, rectifiable materials; using less toxic or nontoxic materials; using materials before they are out of date; utilising low-waste technology; applying eco-design to the construction; implementing training or education or training programmes; sorting different types of waste for recycling or reuse; changing over waste among others; and recycling, reusing and remanufacturing materials (Begum, Siwar, Pereira \& Jaafar, 2007).

The construction sector could experience quality, sustainability and economic benefits and minimise the construction cost by applying precise WM (Kulatunga, Amaratunga, Haigh \& Rameezdeen, 2006; Lingard, Graham $\&$ Smithers, 1997). Several elements of achieving cost benefits are affected by cost reduction in material purchasing, transportation costs of materials and waste, waste minimisation and waste disposal and tipping (Bossink \& Brouwers, 1996; Coventry \& Guthrie, 1998; Jaillon, Poon \& Chiang, 2009; Johnston \& Mincks, 1993). Implementing WM can minimise the health risks related to waste disposal, allowing better productivity and safety on to be achieved on construction sites (Gavilan \& Bernold, 1994). Many researchers have highlighted that, to reduce the level of waste in building projects, it is necessary to consider WM in the construction project's planning or design phase (Osmani et al., 2008; Poon, Yu, Wong \& Cheung, 2004). Improving the environmental performance of construction WM it considered to involve the following strategies, starting from the greatest potential benefit (Udawatta, Zuo, Chiveralls \& Zillante, 2015): avoiding and reducing waste production from construction activities, recovering waste materials for reuse and diverting construction and demolition waste from landfill to recycling facilities.

\subsubsection{Saving Energy}

Use of energy in the construction industry accounts for about $40 \%$ of the total energy consumed in the world (Devi \& Palaniappan, 2017). This is caused by rapid urbanisation and infrastructure development. However, 
previous studies on energy use have not provided an accurate quantification of the energy use and emissions of onsite construction processes (Fay, Treloar \& Iyer-Raniga, 2000; Mithraratne \& Vale, 2004; Ramesh, Prakash \& Shukla, 2012).

The swift development of energy consumption has already increased due to issues related to supply, the difficulty of securing energy sources and serious environmental problems, such as global warming and climate change. Therefore, the main goal is the minimisation of the environmental impact by establishing energy efficiency-related policy at regional, national, and international levels, especially in construction (Pérez-Lombard, Ortiz \& Pout, 2008). Globalisation has brought about serious problems for the environment. The growth of communication networks, the enhancement of people's mode of life, imitation of lifestyles in developed countries all involve greater energy consumption patterns. This will result in severe effects on the environment. The efficiency of energy usage will bring about a significant decrease energy consumption, for instance, by securing energy efficiency in buildings, projects or on-site construction (Pérez-Lombard et al., 2008; Radhi, 2008; Saidur, 2009; Yang, Lam \& Tsang, 2008). There are many activities that can be adopted, such as improving the energy efficiency and utilising non-premium fuels in kiln processes, implementing recycled materials in production processes and use of low energy additives or extenders for energy saving in building materials (Choi \& Hwang, 2015).

\subsubsection{How to Increase Efficiency, Handle Waste and Energy in Construction Projects}

Through energy policy, especially in terms of economic incentives, it is possible to significantly reduce the environmental impact of construction processes and enhance their energy efficiency. Such policy consists of the following measures: (1) managing carbon tax to decrease the fuel utilisation per unit of output on the whole and decrease carbon emissions per unit of energy usage; (b) implementing a mineral extraction tax that will drives the usage of recycled materials; (3) applying landfill waste charges, which could drive industry toward recycling mineral wastes, and reuse of exposure and construction wastes; and (4) levying charges for pollution, with the fines always related to the pollution level caused. In the construction industry, the release of sulphur and nitrogen oxides and carbon dioxide from cement outcome could be managed via these measures.

Many approaches are needed for decreasing the environmental impacts of unsustainable construction activities; these are minimising input, carrying out operation processes more efficiently and finding 'greener' material. Several transformations are needed in the construction activity in industry to gain, as follows (Choi \& Hwang, 2015):

- Research concerning the usage of mineral and energy wastes and focus on the implementation of effective measures;

- Development of fuel efficiency measures, such as harnessing waste and repairing inefficient factories;

- Minimising materials used in design and construction, with a focus on containing energy for recycling, durability and flexibility.

- Minimising energy utilisation by concentrating on decreasing and recycling site waste; and

- Minimising transportation usage.

All these goals could be integrated in the concept of GSCM in the construction industry. GSCM can be emphasised as supply chain praxis concerning the developing environment, including product design, operations management and customer relationships (Srivastava, 2007). Many GSCM studies have been conducted on the enforcement of environmental supply chain strategies with a view to greater enterprise accomplishment.

\subsubsection{The Manufacturing Industry: How to Handle Supply Chain Management Sustainability Issues in Manufacturing Using Green Supply Chain Management}

SCM is defined as a concept in the material and transportation management approach using the traditional purchasing and logistics functions (Tan, 2001). It starts from the earth, then moves to the manufacturers, distributors, retailers and end costumers. It involves several activities, like planning, product design and improvement, manufacturing, assembly, transportation, warehousing, distribution and customer service. Hence, there is lack of SCM, as it only manages waste products in the end consumer phase. Therefore, several researchers 
have focussed on SCM, finding that investments in greening, or GSCM, can be resource saving, waste reducing and productivity increasing (Porter \& Van der Linde, 1995).

GSCM has been considered in both environment-focussed and SCM literature. The scope of GSCM involves establishing integrated green supply chains from the supplier to customer through the manufacturer, up to RL (Zhu \& Sarkis, 2004). Furthermore, GSCM also referred to integrating environmental thinking into SCM, which consists of the design product, sourcing and selection material, manufacturing processes, final product delivery and end-oflife product management.

\subsection{Green Supply Chain Management in the Manufacturing Industry}

The concept of green is represented by eco-friendliness, social justice and economic development and health. The concept of 'green' does not only mean reduced waste and pollution; rather, it strives toward sustainable industry. Green industry considers energy conservation; material purchasing; processing, packaging, delivering and marketing the product; and reusing, recycling, usage and the waste cycle.

Traditional supply chains move from the raw material state to the end product the customer receives (cradle to grave). However, environmental issues mean that processes are transformed with new operations, such as a recovery stage to minimise the environmental impact (Camgöz-Akdağ \& Beldek, 2017). Thus, the closed loop supply chain 'allows the finished good collected from customers, which are end-of-life products now, and go in to some other processes for recovering them', and this has become a public concern (Beamon, 1999). GSCM, a new concept that has emerged a key driver of business value (Dadhich et al., 2015), is defined as the integration of sustainable practices into upstream and downstream SCM, such as product design, materials management, manufacturing processes, product distribution and end-of-life management of the product; in some cases, it may lead to a reduction in profits. GSCM implies that all the member components of the supply chain have the responsibility of decreasing the unbalanced environmental impacts of supply chain processes to ensure more long-term benefits (Dadhich et al., 2015; Ghobakhloo, Tang, Zulkifli \& Ariffin, 2013). According to Ghobakhloo et al. (2013), GSCM consists of green product design, green materials management, green manufacturing processes, green distribution and marketing and RL.

\subsubsection{Green Product Design}

Designing products opens opportunities to diminish any environmental effects inherent in the establishment of new products and production processes. According to Ghobakhloo et al. (2013), green product design consists of two primary conceptions, namely environmentally conscious design (ECD) and lifecycle assessment (LCA). LCA is defined by its focus on analysing the environmental burdens of processes and products over their entire lifecycle (Buyle, Braet \& Audenaert, 2013). It is considered the core of expanding environmental laws, taxes and regulations. Furthermore, LCA has the function of decreasing negative environmental impacts, and it is used by enterprises to reinforce their product expansion (Gungor \& Gupta, 1999). ECD refers to concepts and practices related to designing products while keeping environmental considerations in mind. ECD is classified into two phases, as follows: design for recycling (DFR), which makes better choices for materials preference possible, and design for disassembly (DFD), which is used by businesses to identify certain product design specifications that decrease the structural complexity by reducing the number of parts, increasing the use of common materials, and selecting fastener and joint types that are easily removable.

\subsubsection{Green Materials Management}

Green materials management is a way of substituting less hazardous activities or materials for more harmful ones. It is classified into two processes, as follows: green materials selection and green materials sourcing. The criteria for materials that can be processed in green materials management include that materials used in a product must be easy to separate, adaptable, or usable for streamlining existing processes (Gungor \& Gupta, 1999; Hervani et al., 2005). 


\subsubsection{Green Manufacturing Processes}

Green manufacturing processes consist of three main phases, as follows: resource utilisation decrement, waste decrement and emission decrement. The goal of green manufacturing processes is the reduction of the consumption of pristine substances and other resources with the aim of minimising the total amount of waste in the manufacturing phase indirectly by decreasing energy and resource utilisation (Srivastava, 2007). For example, green manufacturing can reduce the environmental impact by selecting recycled or reused products. Emission decrement, another important aspect of green manufacturing, aims at emissions reduction, which has two essential characteristics - control and prevention. Control means that emissions and waste are trapped, stored, treated and disposed of using pollution control equipment. Prevention means decreasing, changing or preventing emissions and waste together through better materials substitution, recycling, reuse or process innovation (Ghobakhloo et al., 2013).

\subsubsection{Green Distribution and Marketing}

Green marketing can be defined as the promotion or advertising of products, changes in production processes or packaging changes that are weighed in terms of environmental criteria (Cox, 2008). In addition, green marketing supports a green lifestyle and considers the relationship between a product/service and the environment. Green distribution is a significant component of GSCM due to its potential for having a large positive influence on the environment (Ghobakhloo et al., 2013).

\subsubsection{Reverse Logistics}

RL, another significant component of GSCM, has the objective of collecting, distributing and managing products until they are delivered to customers. RL have been used in dealing with unsold product and warrantee returns (Sarkis, 2003). They encompass the recycling, reusing and remanufacturing of materials. Recycling is defined as a procedure for reusing materials that may otherwise be considered waste, but in a form other than that employed in the primary use. The benefits of recycling include extraction of basic materials, diminished energy usage and reduced air and water pollution (Ghobakhloo et al., 2013). Examples of reuse include the utilisation of reusable packaging or shipping materials (Sarkis, 2003). In addition, items can be used again for similar functions via remanufacturing, which is the process of refurbishing and returning used durable products for use to lengthen product lifespan and derive additional value from the original core unit (Sarkis, 2003).

\subsection{Adoption of Green Supply Chain Management for the Construction Industry}

GSCM implementation plays significant roles for manufacturers. Many studies have been conducted to prove the success of GSCM application in the manufacture scope. For example, eco-design has the function of making or repairing products while reducing the environmental impact that the product makes (Zhu, Sarkis \& Lai, 2008b).

To build up a physical environment of society, the most significant field for human civilisation is the construction industry, because its outputs are used for fulfilling all aspects of human activities (Moavenzadeh, 1994). Lifecycle project management is defined as a critical gap between theory and practice in construction management. It has the purpose of utilising the organisation's technical proficiency during a project's lifecycle. According to Kozlovská and Spišáková (2013), the lifecycle of construction consists of four basic phases, as follows: design of construction, realisation of construction, occupation of construction and demolition of construction. Gransberg and Ellicott (1997) classified traditional project management into five separable phases - concept, design, and feasibility study; design; construction; commissioning; and closeout warranty activities. In the traditional setting, the management and technical assets required to complete each phase may not carry over into the next phase. Therefore, Gransberg and Ellicott (1997) conducted a study on building the team on day one and keeping it together throughout all the phases of the project. The phases are as follows: project team selection, project development, design team selection, predesign activities, concept design, design, construction team selection (construction contract), construction, commissioning, and closeout/warranty actions. 
Construction commonly has serious and unalterable effects on the environment, such as the excessive use of resources, energy consumption, pollution and hazardous waste (CIEC, 1992). Therefore, the concept of sustainable construction is frequently used in terms of rising need for environmental awareness. According to Wyatt (1994), sustainable construction should involve not only in the usability of a building during its lifetime, but also the recycling of material to minimise waste after use. Many studies have shown that GSCM could have massive environmental impact while increasing product quality, enhancing productivity and mitigating the effect of supply chain interference (Lippmann, 1999). Although the advantages of the GSCM approach could be recognised easily, its realisation is difficult.

Global warming issues have become a crucial concern, but constructions still cause water, noise and air pollution. Currently, in construction, materials have the potential to minimise waste, and by implementing GSCM, most construction firms can work sustainably, for example by choosing recyclable materials rather than ordinary ones (Begum, Siwar, Pereira \& Jaafar, 2006). SCM has several distinctive assignments in construction, such as developing the supply chain, integration of the site and supply chain, helping to realise construction matter and indicating a way to resolve problems (Vrijhoef \& Koskela, 2000).

GSCM is defined as the integration of sustainable practices into upstream and downstream SCM to bring about long-term benefits through the application of responsible environmental and social behaviour among all supply chain members (Dadhich et al., 2015; Ghobakhloo et al., 2013; Ortiz, Castells \& Sonnemann, 2009). One example of how GSCM has been applied in the construction industry is in green construction. Green construction is carried out according to the following guideline:

On the premise of ensuring quality, safety and other basic requirements, scientific management and technological progress should be used in engineering construction to maximise the conservation of resources and reduce the construction activities which will bring negative impacts on the environmental, and to improve the goal of four savings (energy, land, water and materials) and environmental protection. (Shi, Zuo, Huang, Huang \& Pullen, 2013)

Therefore, GSCM implementation in construction practice would be an excellent way of reducing construction waste. The value chain in the construction industry consists of three levels - upstream, midstream and downstream, as shown in Figure 1.

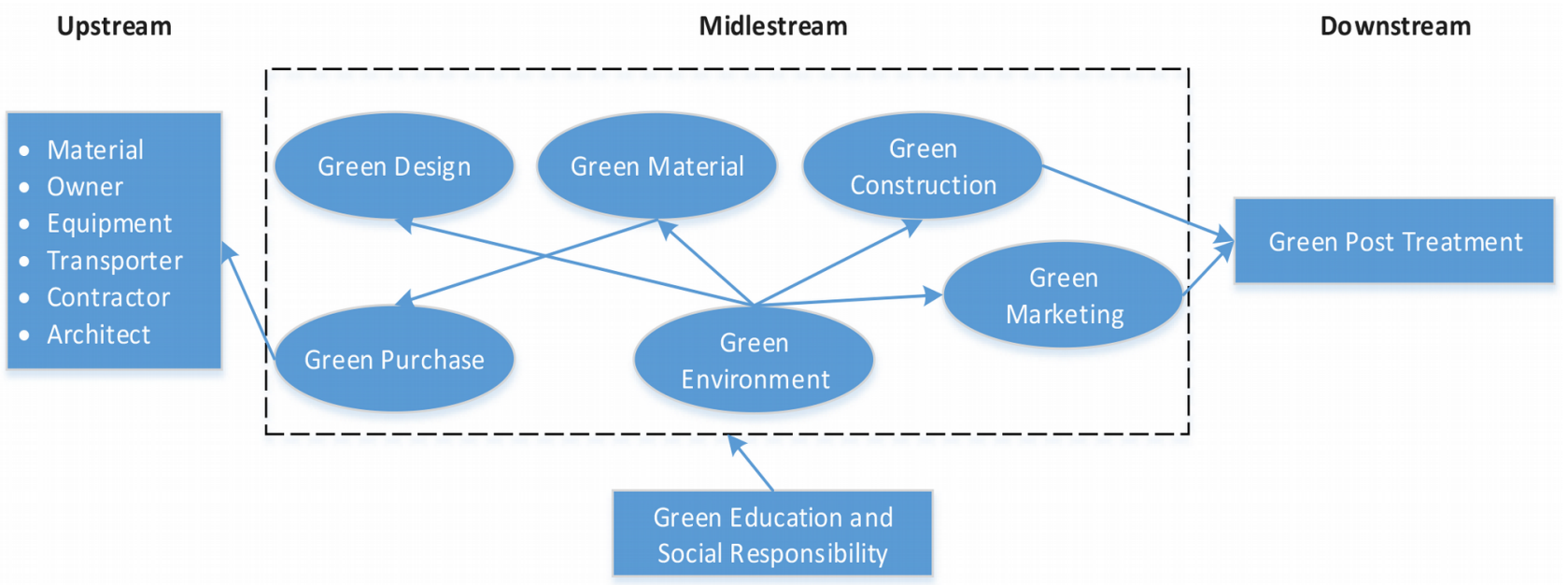

Figure 1. Value chain construction industry (Ghobakhloo et al., 2013)

Accordingly, the present research attempts to classify the dimensions of the GSCM concepts in the construction industry (Figure 2). 


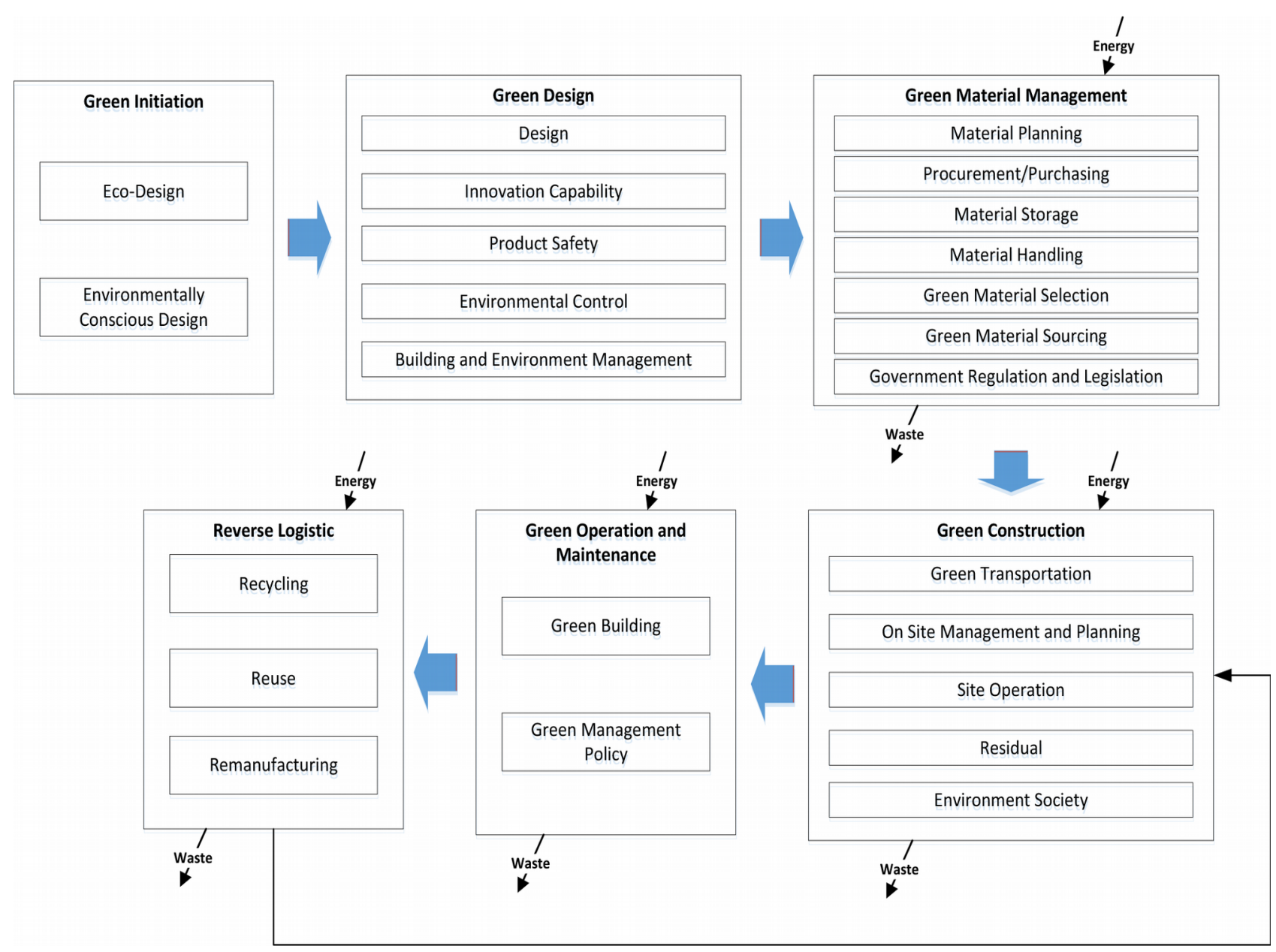

Figure 2. Framework of green supply chain processes for implementation in the construction industry (Ghobakhloo et al., 2013)

The framework of green supply chain process implementation in the construction industry is explained in greater detail below.

\subsubsection{Green Initiation}

Green initiation has been recognised as a main requirement for determining where developers need to design and build sustainable projects that can provide lower energy, water savings and a healthy environment in their projects. (Ali, Jainudin, Tawie \& Jugah, 2016).

\subsubsection{Green Design}

Green design is the most important stage, as conclusions made in the design phase will have a significant effect on the lifecycle environment of the project system. As highlighted by (Zhang, Shen \& Wu, 2011), design should become a major consideration for identifying any possible effects on the project regarding environmental impacts. The concept of green design has the benefit of diminishing the environmental impact resulting from the establishment of construction design and construction processes. The purpose of green design is to design construction projects in environmentally friendly ways. Green designs consist of two main elements, as follows: LCA is used to strengthen the construction development so that the overall negative environmental impact of construction is reduced, while ECD is employed to design construction activities while keeping environmental considerations firmly in mind. Based on the Building Green US Council, green design provides savings of up to $30 \%$ for energy, $35 \%$ for carbon, $30-50 \%$ water usage (Council, U.G.B., 2001). According to Liu, Low and He the selection of sustainable sites, consideration in design of reducing material usage, using more environmental friendly materials and have more natural illumination and ventilation, as well as provisions for water reduction and recycling, are part of green design (Ying-Liu, Pheng-Low \& He, 2012). 


\subsubsection{Green Materials Management}

Green materials management refers to the substitution of potentially hazardous activities or materials with more environmentally friendly ones. It is divided into two processes, as follows: green materials procurement and green materials selection. The criteria in materials selection that can be processed in green materials management include the materials used in construction, which should be easy to separate, adaptable or useful in streamlining existing processes. This highlights four major principles, as delineated below.

- Selecting materials and products effectively and efficiently

Reducing, reusing and recycling materials to minimise source usage, habitat and ecosystem devastation. Utilising durable, reusable, recyclable and renewable materials that can minimise the quantity of materials used.

- Selecting materials and products that reduce contained energy and carbon

The utilisation of materials that contain low energy can bolster this concept; for instance, materials can be used that are produced by non-fossil fuel-based renewable energy resources.

- Avoiding materials and products that can endanger human or environmental health

Materials or products from materials that contain toxins, pollutants and heavy metals should be removed or reduced.

- Selecting materials that contribute to sustainability concepts

Several materials are utilised to develop a sustainable site design feature, although they may not be 'green' separately.

\subsubsection{Green Construction}

Green construction has the purpose of maximising the conservation of resources and reducing construction activities that incur negative impacts for the environment while achieving the goal of savings in the four resource areas (energy, land, water and materials), in addition to ensuring environmental protection. Resource consumption reduction, waste reduction and emissions reduction are general concepts that are integral elements of green construction. According to Shi et al. there are several barriers to green construction, as follows: additional costs for green construction, lack of awareness and knowledge and lack of green suppliers (Shi et al., 2013). Still, several approaches have been developed to overcome these negative features in construction, such as efficient machinery, using segregated waste to enable its reuse/recycling and prefabrication using automation; these measures could minimise onsite waste, and therefore, be less waste generating (Balasubramanian \& Shukla, 2017b).

\subsubsection{Green Operation and Maintenance}

Green operation and maintenance programmes consist of training, clearance, work application and control to preserve 'green' materials in the project in accordance with environmental needs (Hong, Koo, Kim, Lee \& Jeong, 2015).

\subsubsection{Reverse Logistics}

$\mathrm{RL}$ is an activity of initiation and design, practice and managing of construction items and material flows. It involves information flow for effective construction disposal management in the PLC and in line with the basic of the technical and legal criteria (Sobotka \& Czaja, 2015).

\section{Research Methodology}

\subsection{The Purpose of Green Supply Chain Management Standards in the Construction Industry}

The proposed elements of each dimension of GSCM concepts in the construction industry have been broken down into several concepts and dimensions, as illustrated in Table 1. 


\begin{tabular}{|c|c|c|c|}
\hline No. & Concept & Dimension & Reference \\
\hline \multirow[t]{2}{*}{1} & \multirow[t]{2}{*}{$\begin{array}{l}\text { Green } \\
\text { Initiation }\end{array}$} & Eco-design & $\begin{array}{l}\text { Govindan, Rajendran, Sarkis \& Murugesan (2015); Ng, } \\
\text { Wong, Skitmore \& Alin (2012); Shi et al. (2013); Zhang, } \\
\text { Kuo, Lu \& Huang (1997); Zhang et al. (2011) }\end{array}$ \\
\hline & & Environmentally Conscious Design & Ghobakhloo et al. (2013); Zhang et al. (1997) \\
\hline \multirow{5}{*}{2} & \multirow{5}{*}{ Green Design } & Design & $\begin{array}{l}\text { Govindan et al. (2015); Ng et al. (2012); Shi et al. (2013); } \\
\text { Zhang et al. (1997); Zhang et al. (2011) }\end{array}$ \\
\hline & & Innovation Capability & Chen, Shih, Shyur \& Wu (2012) \\
\hline & & Product Safety & $\begin{array}{l}\text { Wang et al. (2013); Zhu, von Zedtwitz, Assimakopoulos } \\
\text { \& Fernandes (2016) }\end{array}$ \\
\hline & & Environmental control & $\begin{array}{l}\text { Green Building Council Indonesia (2010); Ng et al. } \\
\text { (2012); Noci (1997); Zhang et al. (2011); Victoria (1995); } \\
\text { Wang et al. (2013) }\end{array}$ \\
\hline & & Building and Environment Management & Green Building Council Indonesia (2010) \\
\hline \multirow{7}{*}{3} & \multirow{7}{*}{$\begin{array}{l}\text { Green } \\
\text { Materials } \\
\text { Management }\end{array}$} & Material Planning & Melnyk, Sroufe, Montabon \& Calantone (1999) \\
\hline & & Procurement / Purchasing & $\begin{array}{l}\text { Adetunji, Price \& Fleming (2008); Evangelista, } \\
\text { Huge-Brodin, Isaksson \& Sweeney (2012); Hoejmose, } \\
\text { Grosvold \& Millington (2014); Ofori (2000); Yang \& } \\
\text { Zhang (2012) }\end{array}$ \\
\hline & & Material storage & Azevedo, Martins, Teixeira \& Barroso (2014) \\
\hline & & Material handling & Azevedo et al. (2014) \\
\hline & & Green material selection & $\begin{array}{l}\text { Ashby \& Johnson (2002); Ghobakhloo et al. (2013); Tao, } \\
\text { Bi, Zuo \& Nee (2016) }\end{array}$ \\
\hline & & Green material sourcing & Ghobakhloo et al. (2013) \\
\hline & & Government Regulation and Legislation & $\begin{array}{l}\text { Beamon (1999); Hafezalkotob (2017); Min \& Galle } \\
\text { (2001) }\end{array}$ \\
\hline \multirow{5}{*}{4} & \multirow{5}{*}{$\begin{array}{l}\text { Green } \\
\text { Construction }\end{array}$} & Green Transportation & Balasubramanian \& Shukla (2017b) \\
\hline & & On-site Management and planning & Lin \& Chen (2004); Shrestha (2016) \\
\hline & & Site operation & $\begin{array}{l}\text { Hsu \& Hu (2009); Bai \& Sarkis (2010); Muduli, } \\
\text { Govindan, Barve, Kannan \& Geng (2013) }\end{array}$ \\
\hline & & Residual & $\begin{array}{l}\text { Dadhich et al. (2015); Shen \& Tam (2002); Shrestha } \\
\text { (2016); Srivastava (2007); Zhang et al. (2011); Zhu, } \\
\text { Sarkis \& Lai (2008a, 2008b) }\end{array}$ \\
\hline & & Environment Society & $\begin{array}{l}\text { Awasthi, Chauhan \& Goyal (2010); Bai \& Sarkis (2010); } \\
\text { Govindan et al. (2015) }\end{array}$ \\
\hline \multirow[t]{2}{*}{5} & \multirow{2}{*}{$\begin{array}{l}\text { Green } \\
\text { Operation and } \\
\text { Maintenance }\end{array}$} & Green Building & $\begin{array}{l}\text { Chang, Huang, Chuang \& Chang (2016); Paul \& Taylor } \\
\text { (2008); Spiegel \& Meadows (2010); Wei, Ramalho \& } \\
\text { Mandin (2015) }\end{array}$ \\
\hline & & Green Management Policy & Chen et al. (2012) \\
\hline \multirow{3}{*}{6} & \multirow{3}{*}{$\begin{array}{l}\text { Reverse } \\
\text { Logistic }\end{array}$} & Recycling & $\begin{array}{l}\text { Ghobakhloo et al. (2013); Holt \& Ghobadian (2009); } \\
\text { Rao \& Holt (2005); Sarkis (2003) }\end{array}$ \\
\hline & & Reuse & $\begin{array}{l}\text { Chun, Hwang \& Byun (2015); Ghobakhloo et al. (2013); } \\
\text { Holt \& Ghobadian (2009); Rao \& Holt (2005); Sarkis } \\
\text { (2003) }\end{array}$ \\
\hline & & Remanufacture & $\begin{array}{l}\text { Chun et al. (2015); Ghobakhloo et al. (2013); Holt \& } \\
\text { Ghobadian (2009); Rao \& Holt (2005); Sarkis (2003) }\end{array}$ \\
\hline
\end{tabular}

Table 1. Dimensions and Elements of GSCM in the Construction Industry 
Manufacturing consists of five concepts, namely Green Product Design, Green Material Management, Green Manufacturing Processes, Green Distribution and Marketing and RL. Construction also consists of five concepts, as follows: Green Initiation, Green Product Design, Green Material Management, Green Construction, Green Operation and Maintenance and RL. This study reviews the related literature to develop the dimensions of the GSCM concept and construct GSCM indicators based on those dimensions, as shown in Table 2.

\begin{tabular}{|c|c|c|c|}
\hline \multicolumn{2}{|r|}{ Manufacturing } & \multicolumn{2}{|r|}{ Construction } \\
\hline Concept & Definition & Concept & Definition \\
\hline- & - & $\begin{array}{l}\text { Green } \\
\text { Initiation }\end{array}$ & $\begin{array}{l}\text { Green Initiation is discussion between the } \\
\text { owner and consultant concerning the } \\
\text { project lifecycle (PLC), as many } \\
\text { clients/owners are under-informed about } \\
\text { the severity of construction waste. }\end{array}$ \\
\hline $\begin{array}{l}\text { Green Product } \\
\text { Design }\end{array}$ & $\begin{array}{l}\text { Designing products opens opportunities to } \\
\text { diminish any environmental impacts inherent } \\
\text { in the establishment of new products and } \\
\text { production processes. Green product design } \\
\text { consists of two primary conceptions, namely } \\
\text { environmentally conscious design (ECD) and } \\
\text { lifecycle assessment (LCA). LCA focusses on } \\
\text { analysing the environmental burdens of } \\
\text { processes and products over their entire } \\
\text { lifecycle; ECD refers to concepts and practices } \\
\text { related to designing products while keeping } \\
\text { environmental considerations in mind. }\end{array}$ & $\begin{array}{l}\text { Green } \\
\text { Product } \\
\text { Design }\end{array}$ & $\begin{array}{l}\text { Designing buildings opens opportunities } \\
\text { to diminish any environmental impacts } \\
\text { inherent in the establishment of new } \\
\text { design and construction processes. This } \\
\text { includes detailed engineering design } \\
\text { (DED). }\end{array}$ \\
\hline $\begin{array}{l}\text { Green } \\
\text { Material } \\
\text { Management }\end{array}$ & $\begin{array}{l}\text { Green material management is a way of } \\
\text { substituting less hazardous activities or } \\
\text { materials for more harmful ones. It is classified } \\
\text { into two processes - green materials selection } \\
\text { and green materials sourcing. Green material } \\
\text { management is supported by activities like } \\
\text { using materials that are easy to separate or not } \\
\text { fixed, using adaptable materials, using fewer } \\
\text { 'secondary operations' and using a small } \\
\text { numbers of diverse materials in a single } \\
\text { product. }\end{array}$ & $\begin{array}{l}\text { Green } \\
\text { Material } \\
\text { Management }\end{array}$ & $\begin{array}{l}\text { Green material management is a way of } \\
\text { substituting less hazardous activities or } \\
\text { materials for more harmful ones. It is } \\
\text { classified into three processes, namely } \\
\text { green procurement, green materials } \\
\text { selection and green materials sourcing. }\end{array}$ \\
\hline $\begin{array}{l}\text { Green } \\
\text { Manufacturing } \\
\text { Processes }\end{array}$ & $\begin{array}{l}\text { Green manufacturing processes consist of } \\
\text { three main phases - resource utilisation } \\
\text { reduction, waste reduction, and emission } \\
\text { reduction. The goal of green manufacturing } \\
\text { processes is the reduction of the consumption } \\
\text { of pristine substances and other resources } \\
\text { with the aim of indirectly minimising the total } \\
\text { amount of waste at the manufacturing phase } \\
\text { by decreasing energy and resource utilisation. }\end{array}$ & $\begin{array}{l}\text { Green } \\
\text { Construction }\end{array}$ & $\begin{array}{l}\text { Green construction processes consist of } \\
\text { three main phases - resource utilisation } \\
\text { decrement, waste decrement and emission } \\
\text { decrement. The goal of green } \\
\text { construction is the reduction of the } \\
\text { consumption of pristine substances and } \\
\text { other resources with the aim of indirectly } \\
\text { minimising the total amount of waste at } \\
\text { the construction phase by decreasing } \\
\text { energy and resource utilisation. It } \\
\text { comprises on-site green techniques } \\
\text { concentrating on energy use, waste and air } \\
\text { and noise pollution (Ofori, 2000). In the } \\
\text { design phase, the construction waste is } \\
\text { seldom generated, and it frequently or } \\
\text { mostly produced in on-site construction } \\
\text { (Osmani, Glass \& Price, 2008). }\end{array}$ \\
\hline
\end{tabular}




\begin{tabular}{|c|c|c|c|}
\hline \multicolumn{2}{|r|}{ Manufacturing } & \multicolumn{2}{|r|}{ Construction } \\
\hline Concept & Definition & Concept & Definition \\
\hline $\begin{array}{l}\text { Green } \\
\text { Distribution } \\
\text { and Marketing }\end{array}$ & $\begin{array}{l}\text { Green marketing refers to the promotion or } \\
\text { advertising of products, changes in production } \\
\text { processes or packaging changes that are } \\
\text { weighed in terms of environmental criteria. } \\
\text { Green marketing supports a green lifestyle and } \\
\text { considers the relationship between a } \\
\text { product/service and the environment. Green } \\
\text { distribution is a significant component of } \\
\text { GSCM due to its potential for having a large } \\
\text { positive impact on the environment. }\end{array}$ & - & - \\
\hline- & - & $\begin{array}{l}\text { Green } \\
\text { Operation } \\
\text { and } \\
\text { Maintenance }\end{array}$ & $\begin{array}{l}\text { A Green Operations and Maintenance } \\
\text { programme is a plan combining cleaning, } \\
\text { work practices, training and surveillance } \\
\text { with materials in a project in environment- } \\
\text { concerning or well circumstances. }\end{array}$ \\
\hline $\begin{array}{l}\text { Reverse } \\
\text { Logistics (RL) }\end{array}$ & $\begin{array}{l}\text { RL, another significant component of GSCM, } \\
\text { has the objective of collecting, distributing and } \\
\text { managing products until they are delivered to } \\
\text { customers. RL have been used in dealing with } \\
\text { unsold product and warrantee returns. It } \\
\text { encompasses the recycling, reusing and } \\
\text { remanufacturing of materials. Recycling is } \\
\text { defined as a procedure for reusing materials } \\
\text { that may otherwise be considered waste, but in } \\
\text { a form other than the primary use. The } \\
\text { benefits of recycling include extraction of } \\
\text { basic materials, diminished energy usage, and } \\
\text { reduced air and water pollution. Reuse refers } \\
\text { to usage of a product more than once, such as } \\
\text { using it again for the same or a different } \\
\text { function. Remanufacturing can be explained as } \\
\text { repairing a product to lengthen the life of the } \\
\text { original core product. }\end{array}$ & $\begin{array}{l}\text { Reverse } \\
\text { Logistics } \\
\text { (RL) }\end{array}$ & $\begin{array}{l}\text { RL is an activity of initiation and design, } \\
\text { practice and managing of construction } \\
\text { items and material flows. It involves } \\
\text { information flow for effective } \\
\text { construction disposal management in the } \\
\text { PLC and in line with the basic of the } \\
\text { technical and legal criteria (Sobotka \& } \\
\text { Czaja, 2015). One example of RL in the } \\
\text { construction industry is wood recovery, as } \\
\text { structural material requires selecting } \\
\text { potentially usable elements, followed by } \\
\text { processing, destructive testing and } \\
\text { mycological evaluation (Sobotka, Sagan, } \\
\text { Baranowska \& Mazur, 2017) }\end{array}$ \\
\hline
\end{tabular}

Table 2. Operational Definition of GSCM

\subsection{Applicability of the Method for the Research Question}

This study aims to develop a framework for the GSCM standard in the construction industry in Indonesia. Specifically, the purpose of this study is to promote the relevant GSCM constructs, thereby developing a comprehensive GSCM assessment framework that captures the interrelationships between the constructs. Based on the literature review, there are a few researchers in this field. Especially in Indonesia, there has been no research conducted on the implementation of the GSCM model in the Construction Industry. To solve this problem requires expert opinion to justify the issue both theoretically and empirically. The Delphi method permits expert judgment to be recognised and requires chances for structured feedback among experts. Therefore, using the Delphi method is an excellent choice for evaluating the understanding of the research problem.

This study identifies some experts' opinions on GSCM, which is applied in the construction industry. The Delphi technique has been utilised to capture the ideas of those experts (Handayani, Cakravastia, Diawati \& Bahagia, 2012). The method aims to realise the strongest consensus within a group of experts; it creates group communication, and thus, the group and individuals can elaborate to solve a complicated matter (Linstone \& Turoff, 1975; Okoli \& Pawlowski, 2004). The Delphi method consists of the three following activities:

1. Gathering the ideas of a specialist group, commonly using a survey;

2. Synthesising and statistically summarising these ideas; and 
3. Stipulating feedback to the participants and checking if any adjustment is necessitated.

\subsection{The Selection of Experts}

The critical area for validating the Delphi method is determining how to choose experts/specialists to elicit the correct type of knowledge. An expert is a professionally qualified person who has credentials in the area of research. Experts were chosen based on research expertise and publications in the supply chain area. The respondents' selection used expert judgment sampling based on expertise.

In this research, four different sets of experts were selected: academic/researchers, contractors, architects and consultants. The purpose was establishing several interest groups and includes their thinking in the study. Sixteen respondents were involved in this research. In the first round, five respondents did not bring back the questionnaire. In the second round, the 11 respondents who completed questionnaires in the first round were included, and the same respondents were included in the third round.

Validation of the output was conducted by dividing the respondents into two groups. The goal was to compare the output between the first and second groups: If the results were the same, then the instrument would be valid. Both groups showed the same results.

\subsection{Number of Polls and Content of Three Polls}

A Delphi study is supposed to proceed until no further insights are acquired (Linstone \& Turoff, 1975). In truth, it seems impossible to have more than three polls in such research. The content and results of each round are described more specifically below. Overall, the aim was to engage in an ideal process of consolidation, brainstorming and evaluation. In this study, the Delphi process was executed in three rounds. The three steps used in this study are shown in Table 3.

\begin{tabular}{|l|c|c|c|}
\hline & $1^{\text {st }}$ round & $2^{\text {nd }}$ round & $3^{\text {rd }}$ round \\
\hline Definition of Green SCM in the Construction Industry & Draft & Verification & - \\
\hline Concept, Dimensions and Element of GSCM in the Construction Industry & Draft & Verification & Verification \\
\hline KPI of GSCM in Construction Industry & - & - & A draft \\
\hline
\end{tabular}

Table 3. Steps of the Delphi Method in this Research

As the first step, a literature review on GSCM in the Construction Industry, including the definition, concepts, dimensions and elements, as well as key performance indicators (KPIs) of GSCM in the Construction Industry, was carried out. This activity reduced the iterations of the Delphi method. The results of the literature review were clarified in the previous section.

\subsection{Data Collection and Response Rate}

The data were gathered between March and October 2017. The Delphi questionnaires were given directly to the expert respondents, who could write or ask questions about the research contents and fill in the questionnaires. There were 11 responses to each poll, resulting in an average response rate of about 90\%, as shown in Table 4 .

\begin{tabular}{|l|r|r|r|r|r|}
\multicolumn{1}{|c|}{ Group } & Architects & \multicolumn{1}{c|}{ Academics } & Contractors & Consultants & Response rate \\
\hline $1^{\text {st }}$ round & 2 & 8 & 4 & 2 & $69 \%$ \\
\hline $2^{\text {nd }}$ round & 1 & 4 & 4 & 2 & $100 \%$ \\
\hline $3^{\text {rd }}$ round & 1 & 4 & 4 & 2 & $100 \%$ \\
\hline
\end{tabular}

Table 4. Response Rates across the Participant Groups and Rounds 


\subsection{Data Analysis}

The 11 feedback forms obtained in the first round were collected and assessed for similarities. The results of each round were as follows: In the first round, the respondents were asked about the definition of GSCM in the construction industry adopted from (Ghobakhloo et al., 2013). The consensus was that the GSCM concept includes Green Initiation, green design, green material management, the green construction process and green operation and maintenance. Based on the respondents' opinions, RL is a dimension of the green construction process, and it is not a separate concept of GSCM as in the manufacturing industry. In the manufacturing industry, RL encompasses the recycling, reuse and remanufacturing of materials (Ballou, 2007; Love, Irani \& Edwards, 2004). Furthermore, items produced can be used again for similar functions via remanufacturing. RL is a relatively settled field in manufacturing, whereas its uptake in the construction industry is limited (Kibert, 2012; Leigh \& Patterson, 2006; Schultmann \& Sunke, 2007). In the construction industry, RL should be observed in that the knowledge and experience in the recovery of raw materials and construction products should be considered in the process of design and construction. With this understanding, in the second round, RL was included as a dimension of the green construction process.

In this step, there were several inputs from the respondents about elements of the GSCM dimensions, as follows: (1) passive design, module consideration and eco-business model/concepts are elements of the eco-design dimension of the Green Initiation concepts; (2) prefabricated use is an element of the design dimension of the green product design concepts; (3) economic change is an element of the force dimension of the green construction concepts; and (4) a certificate of building proper function (SLF) is element of the green management policy dimension of green operation and maintenance. All these elements were included in the second-round brainstorming using the Delphi method.

The first-round results were collected, analysed and synthesised into an updated framework of GSCM in the construction industry. To synthesise the outcomes of the first step, we organised reviews that were mainly identical, although expressed differently If the content material became identical, but merely differed in expression, we mixed the responses and edited them to obtain a summary response reflecting this content. If there were significant versions, then we mixed the responses but pressured wherein the variations passed off, so that in the second round, the specialists could respond directly to wherein consensus became now not performed. Several respondent opinions added to this research by complementing our assessment components.

In the second round, the experts were given feedback to validate or approve the outcome from the first round and accomplish the distinctions emphasised in the first round. The outcomes were synthesised and analysed to achieve a consensus model that was delivered to be examined again in the third round. In this step, respondents verified the concepts, dimensions and elements of the GSCM framework in the construction industry.

Finally, in the third round, no supplementary information was sought from the experts; rather, we clarified the model and reached a consensus. The consensus was proven by variance calculation of each criterion, which was found to be equal to or less than 0.2. The calculation result was indicated for each item agreed on by 8 out of 11 respondents and variation equal to or less than 0.2. The data collection and variance calculation from the Delphi results for the GSCM concepts in the construction industry are as shown in Table 5.

\begin{tabular}{|c|l|r|r|r|r|r|r|}
\hline \multirow{2}{*}{ No. } & \multirow{2}{*}{ Concept of GSCM } & \multicolumn{3}{|c|}{ Modus } & \multicolumn{3}{|c|}{ Variance } \\
\cline { 2 - 7 } & R 1 & R 2 & R 3 & R 1 & R 2 & R 3 \\
\hline 1 & Green Initiation & 7 & 9 & 10 & 0.255 & 0.164 & 0.091 \\
\hline 2 & Green Product Design & 11 & 11 & 11 & 0.000 & 0.000 & 0.000 \\
\hline 3 & Green Material Management & 9 & 9 & 10 & 0.164 & 0.164 & 0.091 \\
\hline 4 & Green Construction & 10 & 10 & 10 & 0.091 & 0.091 & 0.091 \\
\hline 5 & Green Operation and Maintenance & 8 & 10 & 10 & 0.218 & 0.091 & 0.091 \\
\hline 6 & Reverse Logistics & 4 & 3 & 3 & 0.255 & 0.218 & 0.218 \\
\hline
\end{tabular}

Table 5. Delphi Results for GSCM Concepts in the Construction Industry 
Based on feedback from the experts, in the construction industry, RL is not a concept of GSCM; rather, it is a dimension of green construction. Thus, in the second Delphi round, this concept was included as a dimension of green construction. The occurrence of consensus among the experts involved can be seen from the value of data variance. If the value of variance is less than or equal to 0.2 , then consensus is considerably happened. The results of data processing using the Delphi method for GSCM dimensions in the construction industry are shown in Table 6, while for GSCM elements in the construction industry are shown in Table 7.

\begin{tabular}{|c|c|c|c|c|c|c|c|c|}
\hline \multirow[b]{2}{*}{ No. } & \multirow[b]{2}{*}{ Concepts of GSCM } & \multirow[b]{2}{*}{ Dimensions of GCSM } & \multicolumn{3}{|c|}{ Modus } & \multicolumn{3}{|c|}{ Variance } \\
\hline & & & $\mathbf{R} 1$ & $\mathbf{R} 2$ & R 3 & $\mathbf{R} 1$ & $\mathbf{R} 2$ & $\mathbf{R} 3$ \\
\hline \multirow{2}{*}{1} & \multirow{2}{*}{ Green Initiation } & Eco-design & 11 & 11 & 11 & 0.000 & 0.000 & 0.000 \\
\hline & & Environmentally Conscious Design & 9 & 10 & 10 & 0.164 & 0.091 & 0.091 \\
\hline \multirow{5}{*}{2} & \multirow{5}{*}{$\begin{array}{l}\text { Green Product } \\
\text { Design }\end{array}$} & Design & 9 & 10 & 10 & 0.164 & 0.091 & 0.091 \\
\hline & & Innovation Capability & 8 & 9 & 10 & 0.218 & 0.164 & 0.091 \\
\hline & & Product safety & 10 & 10 & 10 & 0.091 & 0.091 & 0.091 \\
\hline & & Environmental control & 9 & 10 & 10 & 0.164 & 0.091 & 0.091 \\
\hline & & Building and Environment Management & 10 & 10 & 11 & 0.091 & 0.091 & 0.000 \\
\hline \multirow{7}{*}{3} & \multirow{7}{*}{$\begin{array}{l}\text { Green Material } \\
\text { Management }\end{array}$} & Material Planning & 9 & 10 & 10 & 0.164 & 0.091 & 0.091 \\
\hline & & Procurement / Purchasing & 10 & 10 & 10 & 0.091 & 0.091 & 0.091 \\
\hline & & Material storage & 7 & 9 & 10 & 0.255 & 0.164 & 0.091 \\
\hline & & Material handling & 9 & 10 & 10 & 0.164 & 0.091 & 0.091 \\
\hline & & Green material selection & 10 & 10 & 10 & 0.091 & 0.091 & 0.091 \\
\hline & & Green material sourcing & 10 & 10 & 10 & 0.091 & 0.091 & 0.091 \\
\hline & & Government Regulation and Legislation & 7 & 9 & 11 & 0.255 & 0.164 & 0.000 \\
\hline \multirow{6}{*}{4} & \multirow{6}{*}{ Green Construction } & Green Transportation & 8 & 9 & 10 & 0.218 & 0.164 & 0.091 \\
\hline & & On-site Management and planning & 8 & 8 & 9 & 0.218 & 0.218 & 0.164 \\
\hline & & Site operation & 7 & 8 & 10 & 0.255 & 0.218 & 0.091 \\
\hline & & Residual & 7 & 9 & 10 & 0.255 & 0.164 & 0.091 \\
\hline & & Environment Society & 8 & 10 & 10 & 0.218 & 0.091 & 0.091 \\
\hline & & Reverse Logistic & 6 & 7 & 9 & 0.273 & 0.255 & 0.164 \\
\hline \multirow{2}{*}{5} & \multirow{2}{*}{$\begin{array}{l}\text { Green Operation and } \\
\text { Maintenance }\end{array}$} & Green Building & 9 & 9 & 9 & 0.164 & 0.164 & 0.164 \\
\hline & & Green Management Policy & 7 & 9 & 9 & 0.255 & 0.164 & 0.164 \\
\hline
\end{tabular}

Table 6. Delphi Results for the GSCM Dimensions in the Construction Industry

\begin{tabular}{|c|c|c|c|c|c|c|c|c|c|}
\hline \multirow[b]{2}{*}{ No } & \multicolumn{3}{|c|}{ Green SCM } & \multicolumn{3}{|c|}{ Modus } & \multicolumn{3}{|c|}{ Variance } \\
\hline & Concept & Dimension & Element & $\mathbf{R} 1$ & $\mathbf{R} 2$ & R3 & $\mathbf{R} 1$ & $\mathbf{R} 2$ & $\mathbf{R} 3$ \\
\hline \multirow{5}{*}{1} & \multirow{5}{*}{$\begin{array}{l}\text { Green } \\
\text { Initiation }\end{array}$} & \multirow{4}{*}{ Eco-design } & Lifecycle Analysis & 8 & 9 & 10 & 0.218 & 0.164 & 0.091 \\
\hline & & & Passive design & 1 & 7 & 8 & 0.091 & 0.255 & 0.218 \\
\hline & & & Module considerations & 1 & 9 & 9 & 0.091 & 0.164 & 0.164 \\
\hline & & & Eco-business model/concept & 1 & 8 & 9 & 0.091 & 0.218 & 0.164 \\
\hline & & $\begin{array}{l}\text { Environmentally } \\
\text { Conscious } \\
\text { Design }\end{array}$ & $\begin{array}{l}\text { Design products with certain } \\
\text { environmental considerations }\end{array}$ & 9 & 11 & 11 & 0.164 & 0.000 & 0.000 \\
\hline
\end{tabular}




\begin{tabular}{|c|c|c|c|c|c|c|c|c|c|}
\hline \multirow[b]{2}{*}{ No } & \multicolumn{3}{|l|}{ Green SCM } & \multicolumn{3}{|c|}{ Modus } & \multicolumn{3}{|c|}{ Variance } \\
\hline & Concept & Dimension & Element & $\mathbf{R} 1$ & $\mathbf{R} 2$ & R3 & R1 & $\mathbf{R} 2$ & $\mathbf{R} 3$ \\
\hline \multirow{16}{*}{2} & \multirow{16}{*}{$\begin{array}{l}\text { Green } \\
\text { Product } \\
\text { Design }\end{array}$} & \multirow{6}{*}{ Design } & Design changes & 7 & 8 & 9 & 0.255 & 0.218 & 0.164 \\
\hline & & & $\begin{array}{l}\text { Design and detailing } \\
\text { complexity }\end{array}$ & 6 & 7 & 8 & 0.273 & 0.255 & 0.218 \\
\hline & & & $\begin{array}{l}\text { Design and construction } \\
\text { detail errors }\end{array}$ & 7 & 8 & 8 & 0.255 & 0.218 & 0.218 \\
\hline & & & $\begin{array}{l}\text { Unclear and unsuitable } \\
\text { specification }\end{array}$ & 7 & 7 & 7 & 0.255 & 0.255 & 0.255 \\
\hline & & & $\begin{array}{l}\text { Poor communication and } \\
\text { coordination }\end{array}$ & 7 & 7 & 7 & 0.255 & 0.255 & 0.255 \\
\hline & & & Prefabricated use & 1 & 7 & 8 & 0.091 & 0.255 & 0.218 \\
\hline & & \multirow{2}{*}{$\begin{array}{l}\text { Innovation } \\
\text { Capability }\end{array}$} & $\begin{array}{l}\text { Resource conservation and } \\
\text { waste management }\end{array}$ & 10 & 10 & 10 & 0.091 & 0.091 & 0.091 \\
\hline & & & $\begin{array}{l}\text { Appropriate Site } \\
\text { Development }\end{array}$ & 10 & 10 & 10 & 0.091 & 0.091 & 0.091 \\
\hline & & \multirow{2}{*}{ Product safety } & $\begin{array}{l}\text { Occupational health and } \\
\text { safety }\end{array}$ & 8 & 8 & 9 & 0.218 & 0.218 & 0.164 \\
\hline & & & Indoor Health and Comfort & 9 & 9 & 9 & 0.164 & 0.164 & 0.164 \\
\hline & & \multirow{4}{*}{$\begin{array}{l}\text { Environmental } \\
\text { control }\end{array}$} & Pollution prevention & 10 & 10 & 10 & 0.091 & 0.091 & 0.091 \\
\hline & & & $\begin{array}{l}\text { Energy Efficiency and } \\
\text { Conservation }\end{array}$ & 10 & 10 & 10 & 0.091 & 0.091 & 0.091 \\
\hline & & & Water Conservation & 11 & 11 & 11 & 0.000 & 0.000 & 0.000 \\
\hline & & & $\begin{array}{l}\text { Material Resource and } \\
\text { Recycle }\end{array}$ & 10 & 10 & 11 & 0.091 & 0.091 & 0.000 \\
\hline & & \multirow{2}{*}{$\begin{array}{l}\text { Building and } \\
\text { Environment } \\
\text { Management }\end{array}$} & $\begin{array}{l}\text { Environment Collaboration } \\
\text { with Customer }\end{array}$ & 8 & 9 & 11 & 0.218 & 0.164 & 0.000 \\
\hline & & & Environment Assessment & 11 & 11 & 11 & 0.000 & 0.000 & 0.000 \\
\hline \multirow{8}{*}{3} & \multirow{8}{*}{$\begin{array}{l}\text { Green } \\
\text { Material } \\
\text { Management }\end{array}$} & Material Planning & $\begin{array}{l}\text { Using environmentally } \\
\text { friendly material }\end{array}$ & 11 & 11 & 11 & 0.000 & 0.000 & 0.000 \\
\hline & & $\begin{array}{l}\text { Green } \\
\text { Procurement/ } \\
\text { Purchasing }\end{array}$ & Contract with supplier & 9 & 9 & 10 & 0.164 & 0.164 & 0.091 \\
\hline & & \multirow{3}{*}{ Material storage } & $\begin{array}{l}\text { Inappropriate site storage } \\
\text { space leading to damage or } \\
\text { deterioration }\end{array}$ & 7 & 8 & 9 & 0.255 & 0.218 & 0.164 \\
\hline & & & Improper storing methods & 6 & 6 & 6 & 0.273 & 0.273 & 0.273 \\
\hline & & & $\begin{array}{l}\text { Materials stored far away } \\
\text { from point of application }\end{array}$ & 4 & 4 & 6 & 0.255 & 0.255 & 0.273 \\
\hline & & \multirow[t]{3}{*}{ Material handling } & $\begin{array}{l}\text { Materials supplied in loose } \\
\text { form }\end{array}$ & 7 & 8 & 8 & 0.255 & 0.218 & 0.218 \\
\hline & & & $\begin{array}{l}\text { On-site transportation } \\
\text { methods from storage to the } \\
\text { point of application }\end{array}$ & 7 & 8 & 9 & 0.255 & 0.218 & 0.164 \\
\hline & & & Inadequate material handling & 7 & 8 & 8 & 0.255 & 0.218 & 0.218 \\
\hline
\end{tabular}




\begin{tabular}{|c|c|c|c|c|c|c|c|c|c|}
\hline \multirow[b]{2}{*}{ No } & \multicolumn{3}{|l|}{ Green SCM } & \multicolumn{3}{|c|}{ Modus } & \multicolumn{3}{|c|}{ Variance } \\
\hline & Concept & Dimension & Element & $\mathbf{R} 1$ & $\mathbf{R} 2$ & R3 & $\mathbf{R} 1$ & $\mathbf{R} 2$ & $\mathbf{R} 3$ \\
\hline & & \multirow{2}{*}{$\begin{array}{l}\text { Green material } \\
\text { selection }\end{array}$} & Quality Control of Material & 11 & 11 & 11 & 0.000 & 0.000 & 0.000 \\
\hline & & & $\begin{array}{l}\text { Material use environmental } \\
\text { considerations }\end{array}$ & 11 & 11 & 11 & 0.000 & 0.000 & 0.000 \\
\hline & & \multirow{2}{*}{$\begin{array}{l}\text { Green material } \\
\text { sourcing }\end{array}$} & Certified supplier & 10 & 11 & 11 & 0.091 & 0.000 & 0.000 \\
\hline & & & $\begin{array}{l}\text { Supplier committed to } \\
\text { environmental considerations }\end{array}$ & 10 & 10 & 10 & 0.091 & 0.091 & 0.091 \\
\hline & & \multirow{2}{*}{$\begin{array}{l}\text { Government } \\
\text { Regulation and } \\
\text { Legislation }\end{array}$} & Environment Certification & 9 & 10 & 11 & 0.164 & 0.091 & 0.000 \\
\hline & & & Eco-labelling certification & 8 & 10 & 11 & 0.178 & 0.091 & 0.000 \\
\hline \multirow{21}{*}{4} & \multirow{21}{*}{$\begin{array}{l}\text { Green } \\
\text { Construction }\end{array}$} & \multirow{5}{*}{$\begin{array}{l}\text { Green } \\
\text { Transportation }\end{array}$} & Emission reduction & 10 & 10 & 10 & 0.091 & 0.091 & 0.091 \\
\hline & & & $\begin{array}{l}\text { Damage during } \\
\text { transportation }\end{array}$ & 6 & 6 & 8 & 0.273 & 0.273 & 0.218 \\
\hline & & & $\begin{array}{l}\text { Difficulties for delivery } \\
\text { vehicles accessing } \\
\text { construction sites }\end{array}$ & 7 & 7 & 7 & 0.255 & 0.255 & 0.255 \\
\hline & & & $\begin{array}{l}\text { Insufficient protection during } \\
\text { unloading }\end{array}$ & 8 & 8 & 8 & 0.218 & 0.218 & 0.218 \\
\hline & & & $\begin{array}{l}\text { Inefficient methods of } \\
\text { unloading }\end{array}$ & 5 & 7 & 7 & 0.273 & 0.255 & 0.255 \\
\hline & & \multirow{13}{*}{$\begin{array}{l}\text { On-site } \\
\text { Management and } \\
\text { Planning }\end{array}$} & $\begin{array}{l}\text { Lack of on-site waste } \\
\text { management plans }\end{array}$ & 8 & 8 & 8 & 0.218 & 0.218 & 0.218 \\
\hline & & & $\begin{array}{l}\text { Improper planning for } \\
\text { required quantities }\end{array}$ & 10 & 10 & 10 & 0.091 & 0.091 & 0.091 \\
\hline & & & $\begin{array}{l}\text { Delays in passing information } \\
\text { on types and sizes of } \\
\text { materials and components to } \\
\text { be used }\end{array}$ & 7 & 8 & 8 & 0.255 & 0.218 & 0.218 \\
\hline & & & $\begin{array}{l}\text { Lack of on-site material } \\
\text { control }\end{array}$ & 8 & 8 & 8 & 0.218 & 0.218 & 0.218 \\
\hline & & & Lack of supervision & 7 & 8 & 8 & 0.233 & 0.218 & 0.218 \\
\hline & & & Construction cost reduction & 10 & 10 & 10 & 0.091 & 0.091 & 0.091 \\
\hline & & & Waste Management & 9 & 9 & 11 & 0.164 & 0.164 & 0.000 \\
\hline & & & $\begin{array}{l}\text { Pollution Control/ } \\
\text { Environment Treatment }\end{array}$ & 11 & 11 & 11 & 0.000 & 0.000 & 0.000 \\
\hline & & & Quality Control & 11 & 11 & 11 & 0.000 & 0.000 & 0.000 \\
\hline & & & Employment Practices & 11 & 11 & 11 & 0.000 & 0.000 & 0.000 \\
\hline & & & Energy reduction & 11 & 11 & 11 & 0.000 & 0.000 & 0.000 \\
\hline & & & Resource Management & 9 & 10 & 10 & 0.164 & 0.091 & 0.091 \\
\hline & & & Health and Safety & 8 & 8 & 9 & 0.218 & 0.218 & 0.164 \\
\hline & & \multirow[t]{3}{*}{ Site Operation } & Accidents due to negligence & 6 & 7 & 7 & 0.273 & 0.255 & 0.255 \\
\hline & & & $\begin{array}{l}\text { Unused materials and } \\
\text { products }\end{array}$ & 8 & 8 & 9 & 0.218 & 0.218 & 0.164 \\
\hline & & & Equipment malfunction & 9 & 9 & 9 & 0.164 & 0.164 & 0.164 \\
\hline
\end{tabular}




\begin{tabular}{|c|c|c|c|c|c|c|c|c|c|}
\hline \multirow[b]{2}{*}{ No } & \multicolumn{3}{|l|}{ Green SCM } & \multicolumn{3}{|c|}{ Modus } & \multicolumn{3}{|c|}{ Variance } \\
\hline & Concept & Dimension & Element & $\mathbf{R} 1$ & $\mathbf{R} 2$ & $\mathbf{R 3}$ & $\mathbf{R} 1$ & $\mathbf{R} 2$ & $\mathbf{R} 3$ \\
\hline & & & $\begin{array}{l}\text { Use of wrong materials } \\
\text { resulting in their disposal }\end{array}$ & 9 & 9 & 9 & 0.164 & 0.164 & 0.164 \\
\hline & & & Time pressure & 8 & 8 & 8 & 0.218 & 0.218 & 0.218 \\
\hline & & & Poor work ethic & 7 & 7 & 7 & 0.255 & 0.255 & 0.255 \\
\hline & & \multirow{4}{*}{ Residual } & $\begin{array}{l}\text { Waste from application } \\
\text { process (over preparation of } \\
\text { mortar) }\end{array}$ & 9 & 9 & 9 & 0.164 & 0.164 & 0.164 \\
\hline & & & $\begin{array}{l}\text { Offcuts from cutting } \\
\text { materials to length }\end{array}$ & 10 & 10 & 10 & 0.091 & 0.091 & 0.091 \\
\hline & & & $\begin{array}{l}\text { Waste from cutting } \\
\text { uneconomical shapes }\end{array}$ & 9 & 9 & 9 & 0.164 & 0.164 & 0.164 \\
\hline & & & Packaging & 8 & 9 & 9 & 0.218 & 0.164 & 0.164 \\
\hline & & \multirow{3}{*}{$\begin{array}{l}\text { Environment } \\
\text { Society }\end{array}$} & Vandalism & 6 & 7 & 8 & 0.273 & 0.255 & 0.218 \\
\hline & & & Theft & 7 & 7 & 8 & 0.255 & 0.255 & 0.218 \\
\hline & & & Bribery & 7 & 7 & 8 & 0.255 & 0.255 & 0.218 \\
\hline & & \multirow{3}{*}{ Force Majeure } & Weather & 9 & 9 & 9 & 0.164 & 0.164 & 0.164 \\
\hline & & & Disaster & 10 & 10 & 10 & 0.091 & 0.091 & 0.091 \\
\hline & & & Economic change & 1 & 7 & 9 & 0.091 & 0.255 & 0.164 \\
\hline & & \multirow{3}{*}{ Reverse Logistic } & Recycling & 9 & 10 & 10 & 0.164 & 0.091 & 0.091 \\
\hline & & & Reuse & 9 & 9 & 9 & 0.164 & 0.164 & 0.164 \\
\hline & & & Remanufacture & 6 & 8 & 9 & 0.273 & 0.218 & 0.164 \\
\hline \multirow{13}{*}{5} & \multirow{13}{*}{$\begin{array}{l}\text { Green } \\
\text { Operation } \\
\text { and } \\
\text { Maintenance }\end{array}$} & \multirow{9}{*}{ Green Building } & $\begin{array}{l}\text { Greenery (vegetation } \\
\text { planning) }\end{array}$ & 7 & 9 & 9 & 0.255 & 0.164 & 0.164 \\
\hline & & & $\begin{array}{l}\text { Water infiltration and } \\
\text { retention }\end{array}$ & 9 & 9 & 10 & 0.164 & 0.164 & 0.091 \\
\hline & & & Daily energy conservation & 10 & 10 & 10 & 0.091 & 0.091 & 0.091 \\
\hline & & & Water conservation & 8 & 9 & 9 & 0.218 & 0.164 & 0.164 \\
\hline & & & $\mathrm{CO}_{2}$ emission reduction & 11 & 11 & 11 & 0.000 & 0.000 & 0.000 \\
\hline & & & Construction waste reduction & 10 & 10 & 10 & 0.091 & 0.091 & 0.091 \\
\hline & & & $\begin{array}{l}\text { Sewage and waste disposal } \\
\text { facility improvement }\end{array}$ & 10 & 10 & 11 & 0.091 & 0.091 & 0.000 \\
\hline & & & Biodiversity & 8 & 9 & 9 & 0.218 & 0.164 & 0.164 \\
\hline & & & Indoor environment quality & 10 & 10 & 10 & 0.091 & 0.091 & 0.091 \\
\hline & & & $\begin{array}{l}\text { Green Corporate Social } \\
\text { Responsibility }\end{array}$ & 9 & 9 & 10 & 0.164 & 0.164 & 0.091 \\
\hline & & Green & Green Customer Education & 11 & 11 & 11 & 0.000 & 0.000 & 0.000 \\
\hline & & $\begin{array}{l}\text { Management } \\
\text { Policy }\end{array}$ & Green Image Promotion & 9 & 11 & 11 & 0.164 & 0.000 & 0.000 \\
\hline & & & $\begin{array}{l}\text { Certificate of Building } \\
\text { Proper Function }\end{array}$ & 1 & 7 & 9 & 0.091 & 0.255 & 0.164 \\
\hline
\end{tabular}

Table 7. Delphi Results for the GSCM Elements in the Construction Industry 
After reaching a consensus, the final framework for GSCM in the construction industry was obtained. This is showed in Figure 3.

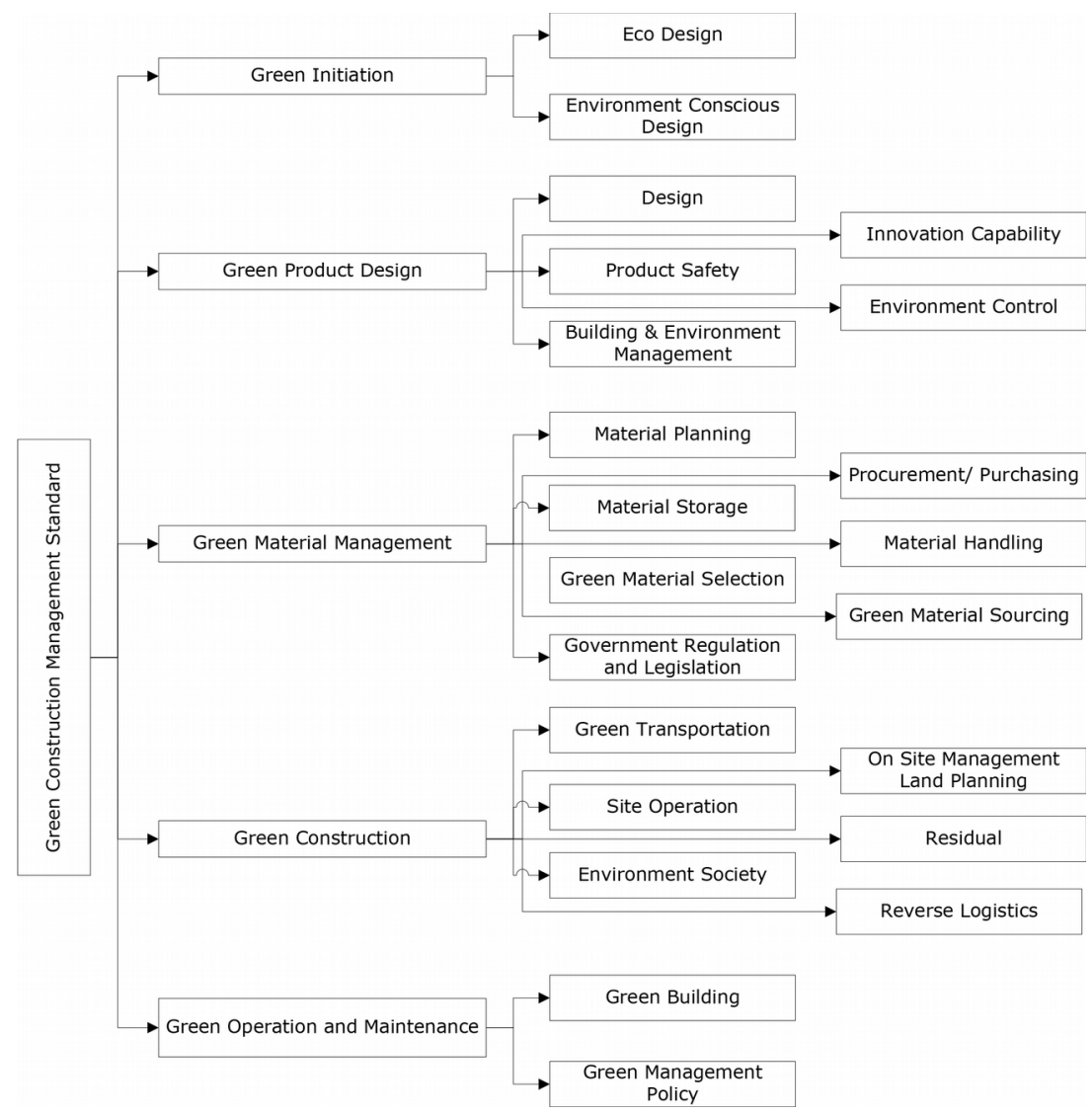

Figure 3. Framework for GSCM in the construction industry

\section{Results and Analysis}

The developing of a standard GSCM framework in the construction industry is needed as a reference for the implementation of GSCM in construction projects. This framework can also be used as an input for the government in providing policy incentives for entrepreneurs in the field of construction who seek to apply the concept of GSCM in their projects. Implementation of the GSCM in construction is expected to overcome the problems of inefficiency, waste reduction and energy usage in construction projects, making the construction projects are more environmentally friendly.

The concept of GSCM in the construction industry was adopted from the GSCM concept in manufacturing, with various adjustments based on PLC. A supply chain-wide management method for environmental control in the form of GSCM has won popularity for manufacturers hoping to mitigate the environmental damage caused by their industry while attaining high operational performance and profits. Meanwhile, PLC management has been carried out ins management of construction initiatives for decades to lessen the whole life price, time, chance and improve the carrier to owners. The PLC includes the phases of initiation, design, construction, and operation and maintenance.

GSCM has emerged as an essential organisational philosophy for reducing environmental risks. Implementation of each phase in the PLC should consider environmental factors regarding construction waste reduction and energy savings. The implementation of GSCM in construction is expected to improve efficiency, reduce waste and save energy usage. This can be done by accomplishing the following: (1) reducing the use of materials in the design and construction stage through the development of building designs that can save energy use and do not result in a lot of wasted material; (2) reducing energy use in the construction process; and (3) reducing the use of transportation 
and material handling during the construction process. Thus, the adoption of the GSCM concept in the construction industry is better able to implement PLC management.

Based on the approach to both concepts, the notion of GSCM in the construction industry has been developed. The GSCM concept consists of green initiation, green design, green material management, green construction and green operation and maintenance, which can be described as follows:

- Green initiation. This developed as a separate concept because, in the construction industry, the owner has a huge role in the process of determining the design concept, material selection and construction cost. The owner is the first party to identify the whole process. The owner's understanding of the construction process is necessary for producing the construction design that will be developed. In construction, there is a standard and rating system related to the sustainability concept. When the owner is willing to go 'green', then there are critical elements of sustainability that must be included as a requirement in the contractual bid document. These essential elements will be the reference in the design process. That is why green initiation is required as a stage before green design'

- Green design. Owner-initiated green measures will be translated into technical language by the Design Consultant. The Design Consultant will work based on the owner's ideas and philosophy. For example, if the owner desires a Green Building built using green construction methods, then all the designs and materials and how to carry out the work will refer to the green philosophy. LCA then becomes a constructive method for the design process, material selection and environmentally friendly implementation;

- Green material management. Based on the owner's initiation and Detailed Engineering Design (DED) produced by the Design Consultant, material selection and execution of the construction depend on when the building is utilised and will refer to eco-friendliness standards. Green material procurement seeks to minimise the energy and embodied carbon, allowing harmful products to be avoided;

- Green Construction. The owner's initiative toward green construction will be applied in several respects, such as the reduction of resource consumption, construction waste, emissions, site layout and use, storage materials, indoor air quality during construction, water efficiency and energy;

- Green distribution and marketing management. This is approached with green operation and maintenance because the construction project prioritises how to operate, manage and maintain buildings or other construction objects. Product distribution and marketing activities can be carried out by third parties. This is different from the manufacturing industry, where the distribution and marketing activities are one of the core activities of the companies beyond the production process itself. The concept of the green building becomes the basis of environmentally friendly operations and maintenance applications. Green Building includes water conversion, reducing energy consumption and indoor air quality.

- RL. In the manufacturing industry, RL encompasses the recycling, reuse and remanufacturing of materials (Ballou, 2007; Love et al., 2004). Furthermore, products can be used again for similar functions via remanufacturing. RL is a relatively settled field in manufacturing, but its uptake in the construction industry is limited (Kibert, 2012; Leigh \& Patterson, 2006; Schultmann \& Sunke, 2007). In the construction industry, for RL, the knowledge and experience in the recovery of raw materials and construction products should be considered in the process of design and construction.

\section{Conclusion}

This paper proposed a conceptual framework for GSCM implementation in the construction industry. By applying the GSCM perspective, this study contributes to developing a GSCM standard in the Construction Industry. The results showed that GSCM comprises five concepts (green initiation, green product design, green material management, green construction, and green operation and maintenance), 22 dimensions, and 86 elements. Based on the framework, an assessment model could be developed that illustrated the KPIs. The assessment model could be used to determine the performance of GSCM implementation in construction projects. Further research will 
explore the instruments of the developed model in detail and conduct empirical studies to validate the assessment instrument.

\section{Declaration of Conflicting Interests}

The authors declared no potential conflicts of interest with respect to the research, authorship, and/or publication of this article.

\section{Funding}

The authors received financial support for the research, authorship, and/or publication of this article from Ministry of Research, Technology, and Higher Education.

\section{References}

Abidin, N.Z. (2010). Investigating the awareness and application of sustainable construction concept by Malaysian developers. Habitat international, 34(4), 421-426. https://doi.org/10.1016/j.habitatint.2009.11.011

Adetunji, I.O., Price, A.D., \& Fleming, P.R. (2008). Achieving sustainability in the construction supply chain. Engineering Sustainability, 161(3), 161-172. https://doi.org/10.1680/ensu.2008.161.3.161

Akintoye, A., McIntosh, G., \& Fitzgerald, E. (2000). A survey of supply chain collaboration and management in the UK construction industry. European Journal of Purchasing \& Supply Management, 6(3), 159-168.

https://doi.org/10.1016/S0969-7012(00)00012-5

Ali, A.N.A., Jainudin, N.A., Tawie, R., \& Jugah, I. (2016). Green Initiatives in Kota Kinabalu Construction Industry. Procedia-Social and Behavioral Sciences, 224, 626-631. https://doi.org/10.1016/j.sbspro.2016.05.453

Ashby, M.F., \& Johnson, K. (2002). Materials and design: the art and science of materials selection in product design. Reino Unido: Elsevier Butterworth Heinemann.

Awasthi, A., Chauhan, S.S., \& Goyal, S.K. (2010). A fuzzy multicriteria approach for evaluating environmental performance of suppliers. International Journal of Production Economics, 126(2), 370-378.

https://doi.org/10.1016/j.ijpe.2010.04.029

Awaysheh, A., \& Klassen, R.D. (2010). The impact of supply chain structure on the use of supplier socially responsible practices. International Journal of Operations \& Production Management, 30(12), 1246-1268. https://doi.org/10.1108/01443571011094253

Azevedo, R., Martins, C., Teixeira, J.C., \& Barroso, M. (2014). Obstacle clearance while performing manual material handling tasks in construction sites. Safety science, 62, 205-213. https://doi.org/10.1016/j.ssci.2013.08.016

Bai, C., \& Sarkis, J. (2010). Integrating sustainability into supplier selection with grey system and rough set methodologies. International Journal of Production Economics, 124(1), 252-264.

https://doi.org/10.1016/j.ijpe.2009.11.023

Balasubramanian, S., \& Shukla, V. (2017a). Green supply chain management: an empirical investigation on the construction sector. Supply Chain Management: An International Journal, 22(1), 58-81. https://doi.org/10.1108/SCM-072016-0227

Balasubramanian, S., \& Shukla, V. (2017b). Green supply chain management: the case of the construction sector in the United Arab Emirates (UAE). Production Planning \& Control, 28(14), 1116-1138.

https://doi.org/10.1080/09537287.2017.1341651

Ballou, R.H. (2007). The evolution and future of logistics and supply chain management. European business review, 19(4), 332-348. https://doi.org/10.1108/09555340710760152 
Beamon, B.M. (1999). Designing the green supply chain. Logistics information management, 12(4), 332-342. https://doi.org/10.1108/09576059910284159

Begum, R.A., Siwar, C., Pereira, J.J., \& Jaafar, A.H. (2006). A benefit-cost analysis on the economic feasibility of construction waste minimisation: the case of Malaysia. Resources, conservation and recycling, 48(1), 86-98.

https://doi.org/10.1016/j.resconrec.2006.01.004

Begum, R.A., Siwar, C., Pereira, J.J., \& Jaafar, A.H. (2007). Implementation of waste management and minimisation in the construction industry of Malaysia. Resources, Conservation and Recycling, 51(1), 190-202.

https://doi.org/10.1016/j.resconrec.2006.09.004

Bohari, A.A.M., Skitmore, M., Xia, B., Teo, M., Zhang, X., \& Adham, K.N. (2015). The path towards greening the Malaysian construction industry. Renewable and Sustainable Energy Reviews, 52, 1742-1748.

https://doi.org/10.1016/j.rser.2015.07.148

Bossink, B., \& Brouwers, H. (1996). Construction waste: quantification and source evaluation. Journal of construction engineering and management, 122(1), 55-60. https://doi.org/10.1061/(ASCE)0733-9364(1996)122:1(55)

BRE (2003). Construction site transport.

Buyle, M., Braet, J., \& Audenaert, A. (2013). Life cycle assessment in the construction sector: A review. Renewable and Sustainable Energy Reviews, 26, 379-388. https://doi.org/10.1016/j.rser.2013.05.001

Camgöz-Akdağ, H., \& Beldek, T. (2017). Waste Management in Green Building Operations Using GSCM. International Journal of Supply Chain Management, 6(3), 174-180.

Chang, Y.-H., Huang, P.-H., Chuang, T.-F., \& Chang, S.-W. (2016). A pilot study of the color performance of recycling green building materials. Journal of Building Engineering, 7, 114-120.

https://doi.org/10.1016/j.jobe.2016.06.001

Chen, C.-C., Shih, H.-S., Shyur, H.-J., \& Wu, K.-S. (2012). A business strategy selection of green supply chain management via an analytic network process. Computers \& Mathematics with Applications, 64(8), 2544-2557.

https://doi.org/10.1016/j.camwa.2012.06.013

Choi, D., \& Hwang, T. (2015). The impact of green supply chain management practices on firm performance: the role of collaborative capability. Operations Management Research, 8(3-4), 69-83. https://doi.org/10.1007/s12063-0150100-x

Chun, S.-H., Hwang, H.J., \& Byun, Y.-H. (2015). Green supply chain management in the construction industry: case of korean construction companies. Procedia-Social and Behavioral Sciences, 186, 507-512.

https://doi.org/10.1016/j.sbspro.2015.04.192

CIEC (1992). Construction and the Environment, Building Employers Confederation, London.

Council, U.G.B. (2001). Leadership in energy and environmental design (LEED).

Coventry, S., \& Guthrie, P. (1998). Waste Minimisation and Recycling in Construction-design Manual. Construction Industry Research and Information Association.

Cox, M.J. (2008). Sustainable Communication: A Study of Green Advertising and Audience Reception within the growing arena of Corporate Social Responsibility, Case Study: British Petroleum. Earth \& E-nvironment, 3, 32-51.

Dadhich, P., Genovese, A., Kumar, N., \& Acquaye, A. (2015). Developing sustainable supply chains in the UK construction industry: a case study. International Journal of Production Economics, 164, 271-284.

https://doi.org/10.1016/j.ijpe.2014.12.012 
Devi, L.P., \& Palaniappan, S. (2017). A study on energy use for excavation and transport of soil during building construction. Journal of cleaner production, 164, 543-556. https://doi.org/10.1016/j.jclepro.2017.06.208

Drohomeretski, E., Gouvea da Costa, S., \& Pinheiro de Lima, E. (2014). Green supply chain management: Drivers, barriers and practices within the Brazilian automotive industry. Journal of Manufacturing Technology Management, 25(8), 1105-1134. https://doi.org/10.1108/JMTM-06-2014-0084

Ekanayake, L.L., \& Ofori, G. (2004). Building waste assessment score: design-based tool. Building and Environment, 39(7), 851-861. https://doi.org/10.1016/j.buildenv.2004.01.007

Evangelista, P., Huge-Brodin, M., Isaksson, K., \& Sweeney, E. (2012). Purchasing green transport and logistics services. Implications for small business.

Fay, R., Treloar, G., \& Iyer-Raniga, U. (2000). Life-cycle energy analysis of buildings: a case study. Building Research \& Information, 28(1), 31-41. https://doi.org/10.1080/096132100369073

Formoso, C.T., Soibelman, L., De Cesare, C., \& Isatto, E.L. (2002). Material waste in building industry: main causes and prevention. Journal of construction engineering and management, 128(4), 316-325. https://doi.org/10.1061/ (ASCE)0733-9364(2002)128:4(316)

Gavilan, R.M., \& Bernold, L.E. (1994). Source evaluation of solid waste in building construction. Journal of construction engineering and management, 120(3), 536-552. https://doi.org/10.1061/(ASCE)0733-9364(1994)120:3(536)

Ghobakhloo, M., Tang, S.H., Zulkifli, N., \& Ariffin, M. (2013). An integrated framework of green supply chain management implementation. International Journal of Innovation, Management and Technology, 4(1), 86.

Gold, S., Seuring, S., \& Beske, P. (2010). Sustainable supply chain management and inter-organizational resources: a literature review. Corporate social responsibility and environmental management, 17(4), 230-245.

Govindan, K., Rajendran, S., Sarkis, J., \& Murugesan, P. (2015). Multi criteria decision making approaches for green supplier evaluation and selection: a literature review. Journal of Cleaner Production, 98, 66-83.

https://doi.org/10.1016/j.jclepro.2013.06.046

Gransberg, D.D., \& Ellicott, M.A. (1997). Life cycle project management. AACE international transactions, 288.

Green Building Council Indonesia (2010). GREENSHIP Versi 1.0. Jakarta.

Green Jr., K.W., Zelbst, P.J., Meacham, J., \& Bhadauria, V.S. (2012). Green supply chain management practices: impact on performance. Supply Chain Management: An International Journal, 17(3), 290-305.

https://doi.org/10.1108/13598541211227126

Guang-Shi, V., Lenny-Koh, S., Baldwin, J., \& Cucchiella, F. (2012). Natural resource based green supply chain management. Supply Chain Management: An International Journal, 17(1), 54-67.

https://doi.org/10.1108/13598541211212203

Gungor, A., \& Gupta, S.M. (1999). Issues in environmentally conscious manufacturing and product recovery: a survey. Computers \& Industrial Engineering, 36(4), 811-853. https:// doi.org/10.1016/S0360-8352(99)00167-9

Hafezalkotob, A. (2017). Competition, cooperation, and coopetition of green supply chains under regulations on energy saving levels. Transportation Research Part E: Logistics and Transportation Review, 97, 228-250.

https://doi.org/10.1016/j.tre.2016.11.004

Handayani, N.U., Cakravastia, A., Diawati, L., \& Bahagia, N. (2012). A conceptual assessment model to identify phase of industrial cluster life cycle in Indonesia. Journal of Industrial Engineering and Management, 5(1), 198.

https://doi.org/10.3926/jiem.447 
Hervani, A.A., Helms, M.M., \& Sarkis, J. (2005). Performance measurement for green supply chain management. Benchmarking: An international journal, 12(4), 330-353. https://doi.org/10.1108/14635770510609015

Hoejmose, S.U., Grosvold, J., \& Millington, A. (2014). The effect of institutional pressure on cooperative and coercive 'green'supply chain practices. Journal of Purchasing and Supply Management, 20(4), 215-224. https://doi.org/10.1016/j.pursup.2014.07.002

Holt, D., \& Ghobadian, A. (2009). An empirical study of green supply chain management practices amongst UK manufacturers. Journal of Manufacturing Technology Management, 20(7), 933-956.

https://doi.org/10.1108/17410380910984212

Hong, T., Koo, C., Kim, J., Lee, M., \& Jeong, K. (2015). A review on sustainable construction management strategies for monitoring, diagnosing, and retrofitting the building's dynamic energy performance: Focused on the operation and maintenance phase. Applied Energy, 155, 671-707. https://doi.org/10.1016/j.apenergy.2015.06.043

Hsu, C.-W., \& Hu, A.H. (2009). Applying hazardous substance management to supplier selection using analytic network process. Journal of Cleaner Production, 17(2), 255-264. https://doi.org/10.1016/j.jclepro.2008.05.004

Irizarry, J., Karan, E.P., \& Jalaei, F. (2013). Integrating BIM and GIS to improve the visual monitoring of construction supply chain management. Automation in construction, 31, 241-254.

https://doi.org/10.1016/j.autcon.2012.12.005

Jaillon, L., Poon, C.-S., \& Chiang, Y. (2009). Quantifying the waste reduction potential of using prefabrication in building construction in Hong Kong. Waste management, 29(1), 309-320.

https://doi.org/10.1016/j.wasman.2008.02.015

Johnston, H., \& Mincks, W.R. (1993). Cost effective waste minimization for the construction manager. AACE International Transactions, O. 2.1.

Kibert, C. (2012). Closing materials loop. Sustainable Construction: Green Building Design and Delivery, 3.

Korczynski, M. (1996). The low-trust route to economic development: inter-firm relations in the UK engineering construction industry in the 1980s and 1990s. Journal of Management Studies, 33(6), 787-808.

https://doi.org/10.1111/j.1467-6486.1996.tb00172.x

Kozlovská, M., \& Spišáková, M. (2013). Contruction waste generation across construction project life-cycle. Organization, Technology \& Management in Construction: An International Journal, 5(1), 687-695.

https://doi.org/10.5592/otmcj.2013.1.5

Kulatunga, U., Amaratunga, D., Haigh, R., \& Rameezdeen, R. (2006). Attitudes and perceptions of construction workforce on construction waste in Sri Lanka. Management of Environmental Quality: An International Journal, 17(1), 57-72. https://doi.org/10.1108/14777830610639440

Leigh, N.G., \& Patterson, L.M. (2006). Deconstructing to redevelop: a sustainable alternative to mechanical demolition: the economics of density development finance and pro formas. Journal of the American Planning Association, 72(2), 217-225. https://doi.org/10.1080/01944360608976740

Lin, C.-W.R., \& Chen, H.-Y.S. (2004). A fuzzy strategic alliance selection framework for supply chain partnering under limited evaluation resources. Computers in Industry, 55(2), 159-179.

https://doi.org/10.1016/j.compind.2004.02.003

Lingard, H., Graham, P., \& Smithers, G. (1997). Waste management in the Australian construction industry: a human factors approach. Paper presented at the 13th Annual ARCOM Conference; Cambridge: Association of Researchers in Construction Management (203-212).

Linstone, H.A., \& Turoff, M. (1975). The delphi method. Addison-Wesley Reading, MA. 
Lippmann, S. (1999). Supply chain environmental management: elements for success. Corporate Environmental Strategy, 6(2), 175-182. https://doi.org/10.1016/S1066-7938(00)80027-5

Love, P.E., Irani, Z., \& Edwards, D.J. (2004). A seamless supply chain management model for construction. Supply Chain Management: An International Journal, 9(1), 43-56. https://doi.org/10.1108/13598540410517575

Luthra, S., Garg, D., \& Haleem, A. (2015). Critical success factors of green supply chain management for achieving sustainability in Indian automobile industry. Production Planning \& Control, 26(5), 339-362.

Malviya, R.K., \& Kant, R. (2015). Green supply chain management (GSCM): a structured literature review and research implications. Benchmarking: An international journal, 22(7), 1360-1394. https://doi.org/10.1108/BIJ-01-20140001

Melnyk, S.A., Sroufe, R., Montabon, F., \& Calantone, R. (1999). Integrating environmental issues into material planning:'green'MRP. Production and inventory management journal, 40(3), 36.

Min, H., \& Galle, W.P. (2001). Green purchasing practices of US firms. International Journal of Operations \& Production Management, 21(9), 1222-1238. https://doi.org/10.1108/EUM0000000005923

Mithraratne, N., \& Vale, B. (2004). Life cycle analysis model for New Zealand houses. Building and Environment, 39(4), 483-492. https://doi.org/10.1016/j.buildenv.2003.09.008

Moavenzadeh, F. (1994). Global construction and the environment: strategies and opportunities. John Wiley \& Sons.

Muduli, K., Govindan, K., Barve, A., Kannan, D., \& Geng, Y. (2013). Role of behavioural factors in green supply chain management implementation in Indian mining industries. Resources, conservation and recycling, 76, 50-60. https://doi.org/10.1016/j.resconrec.2013.03.006

Ng, S.T., Wong, J.M., Skitmore, S., \& Alin, V. (2012). Carbon dioxide reduction in the building life cycle: a critical review. Paper presented at the Proceedings of the Institution of Civil Engineers-Engineering Sustainability. https://doi.org/10.1680/ensu.11.00005

Noci, G. (1997). Designing 'green' vendor rating systems for the assessment of a supplier's environmental performance. European Journal of Purchasing \& Supply Management, 3(2), 103-114. https://doi.org/10.1016/S09697012(96)00021-4

O’Brien, W.J., Formoso, C.T., Ruben, V., \& London, K. (2008). Construction supply chain management handbook. CRC Press. https://doi.org/10.1201/9781420047462

Ofori, G. (2000). Greening the construction supply chain in Singapore. European Journal of Purchasing \& Supply Management, 6(3), 195-206. https://doi.org/10.1016/S0969-7012(00)00015-0

Ojo, E., Mbohwa, C., \& Akinlabi, E.T. (2014). Green supply chain management in construction industries in South Africa and Nigeria. International Journal of Chemical, Environmental \& Biological Sciences (IJCEBS), 2(2).

Okoli, C., \& Pawlowski, S.D. (2004). The Delphi method as a research tool: an example, design considerations and applications. Information \& management, 42(1), 15-29. https:// doi.org/10.1016/j.im.2003.11.002

Ortiz, O., Castells, F., \& Sonnemann, G. (2009). Sustainability in the construction industry: A review of recent developments based on LCA. Construction and Building Materials, 23(1), 28-39.

https://doi.org/10.1016/j.conbuildmat.2007.11.012

Osmani, M., Glass, J., \& Price, A.D.F. (2008). Architects' perspectives on construction waste reduction by design. Waste management, 28(7), 1147-1158. https://doi.org/10.1016/j.wasman.2007.05.011

Paul, W.L., \& Taylor, P.A. (2008). A comparison of occupant comfort and satisfaction between a green building and a conventional building. Building and Environment, 43(11), 1858-1870. https://doi.org/10.1016/j.buildenv.2007.11.006 
Pérez-Lombard, L., Ortiz, J., \& Pout, C. (2008). A review on buildings energy consumption information. Energy and buildings, 40(3), 394-398. https://doi.org/10.1016/j.enbuild.2007.03.007

Perotti, S., Zorzini, M., Cagno, E., \& Micheli, G.J. (2012). Green supply chain practices and company performance: the case of 3PLs in Italy. International Journal of Physical Distribution \& Logistics Management, 42(7), 640-672.

https://doi.org/10.1108/09600031211258138

Poon, C.S., Yu, A.T.W., Wong, S.W., \& Cheung, E. (2004). Management of construction waste in public housing projects in Hong Kong. Construction Management \& Economics, 22(7), 675-689.

https://doi.org/10.1080/0144619042000213292

Porter, M.E., \& Van der Linde, C. (1995). Toward a new conception of the environment-competitiveness relationship. The journal of economic perspectives, 9(4), 97-118. https://doi.org/10.1257/jep.9.4.97

Qi, G., Shen, L.Y., Zeng, S., \& Jorge, O.J. (2010). The drivers for contractors' green innovation: an industry perspective. Journal of Cleaner Production, 18(14), 1358-1365. https://doi.org/10.1016/j.jclepro.2010.04.017

Radhi, H. (2008). A systematic methodology for optimising the energy performance of buildings in Bahrain. Energy and buildings, 40(7), 1297-1303. https://doi.org/10.1016/j.enbuild.2007.11.007

Ramesh, T., Prakash, R., \& Shukla, K. (2012). Life cycle energy analysis of a residential building with different envelopes and climates in Indian context. Applied Energy, 89(1), 193-202.

https://doi.org/10.1016/j.apenergy.2011.05.054

Rao, P., \& Holt, D. (2005). Do green supply chains lead to competitiveness and economic performance? International Journal of Operations \& Production Management, 25(9), 898-916. https://doi.org/10.1108/01443570510613956

Saidur, R. (2009). Energy consumption, energy savings, and emission analysis in Malaysian office buildings. Energy Policy, 37(10), 4104-4113. https://doi.org/10.1016/j.enpol.2009.04.052

Sarkis, J. (2003). A strategic decision framework for green supply chain management. Journal of Cleaner Production, 11(4), 397-409. https://doi.org/10.1016/S0959-6526(02)00062-8

Schultmann, F., \& Sunke, N. (2007). Organisation of reverse logistics tasks in the construction industry. Portugal SB07: Sustainable Construction, Materials and Practices, IOS Press, 978-971.

Shen, L., \& Tam, V.W. (2002). Implementation of environmental management in the Hong Kong construction industry. International Journal of Project Management, 20(7), 535-543. https://doi.org/10.1016/S0263-7863(01)00054-0

Shi, Q., Zuo, J., Huang, R., Huang, J., \& Pullen, S. (2013). Identifying the critical factors for green construction-an empirical study in China. Habitat international, 40, 1-8. https:/ / doi.org/10.1016/j.habitatint.2013.01.003

Shrestha, S. (2016). Comparison of energy efficient and green buildings: technological and policy aspects with case studies from Europe, the USA, India and Nepal (49). Universitätsverlag der TU Berlin.

Sobotka, A., \& Czaja, J. (2015). Analysis of the factors stimulating and conditioning application of reverse logistics in construction. Procedia Engineering, 122, 11-18. https://doi.org/10.1016/j.proeng.2015.10.002

Sobotka, A., Sagan, J., Baranowska, M., \& Mazur, E. (2017). Management of reverse logistics supply chains in construction projects. Procedia Engineering, 208, 151-159. https://doi.org/10.1016/j.proeng.2017.11.033

Sourani, A. (2011). Barriers to addressing sustainable construction in public procurement strategies. Engineering Sustainability, 164(4), 229-237. https://doi.org/10.1680/ensu.2011.164.4.229

Spiegel, R., \& Meadows, D. (2010). Green building materials: a guide to product selection and specification. John Wiley \& Sons. 
Srivastava, S.K. (2007). Green supply-chain management: a state-of-the-art literature review. International journal of management reviews, 9(1), 53-80. https://doi.org/10.1111/j.1468-2370.2007.00202.x

Tam, V.W., Tam, C., Zeng, S., \& Chan, K. (2006). Environmental performance measurement indicators in construction. Building and Environment, 41(2), 164-173. https://doi.org/10.1016/j.buildenv.2005.01.009

Tan, K.C. (2001). A framework of supply chain management literature. European Journal of Purchasing \& Supply Management, 7(1), 39-48. https://doi.org/10.1016/S0969-7012(00)00020-4

Tao, F., Bi, L.N., Zuo, Y., \& Nee, A.Y.C. (2016). A hybrid group leader algorithm for green material selection with energy consideration in product design. CIRP Annals, 65(1), 9-12. https://doi.org/10.1016/j.cirp.2016.04.086

Udawatta, N., Zuo, J., Chiveralls, K., \& Zillante, G. (2015). Improving waste management in construction projects: an Australian study. Resources, Conservation and Recycling, 101, 73-83. https://doi.org/10.1016/j.resconrec.2015.05.003

UN Global Compact. (2010). Supply Chain Sustainability. A Practical Guide for Continuous Improvement, UN Global Compact Office and Business for Social Responsibility. Available at: www.bsr.org/reports/BSRUNGCSupplyChainReport.pdf

UNEP-SBCI (2016). Available at: www.unep.org/sbci/AboutSBCI/Background.asp

Varnäs, A., Balfors, B., \& Faith-Ell, C. (2009). Environmental consideration in procurement of construction contracts: current practice, problems and opportunities in green procurement in the Swedish construction industry. Journal of Cleaner Production, 17(13), 1214-1222. https://doi.org/10.1016/j.jclepro.2009.04.001

Victoria, E. (1995). Environmental Guidelines for Major Construction Sites. Publication.

Vrijhoef, R., \& Koskela, L. (2000). The four roles of supply chain management in construction. European Journal of Purchasing \& Supply Management, 6(3), 169-178. https:/ / doi.org/10.1016/S0969-7012(00)00013-7

Walker, H., \& Jones, N. (2012). Sustainable supply chain management across the UK private sector. Supply Chain Management: An International Journal, 17(1), 15-28. https://doi.org/10.1108/13598541211212177

Wang, Y.-F., Chen, S.-P., Lee, Y.-C., \& Tsai, C.-T.S. (2013). Developing green management standards for restaurants: An application of green supply chain management. International Journal of Hospitality Management, 34, $263-273$. https://doi.org/10.1016/j.ijhm.2013.04.001

Wei, W., Ramalho, O., \& Mandin, C. (2015). Indoor air quality requirements in green building certifications. Building and Environment, 92, 10-19. https://doi.org/10.1016/j.buildenv.2015.03.035

Wibowo, M.A., \& Koestalam, P. (2015). Identification and Analyze of Influence Level on Waste Construction Management of Performance. Procedia Engineering, 125, 46-52. https://doi.org/10.1016/j.proeng.2015.11.008

Wu, J., Dunn, S., \& Forman, H. (2012). A study on green supply chain management practices among large global corporations. Journal of Supply Chain and Operations Management, 10(1), 182-194.

Wu, K.-J., Tseng, M.-L., \& Vy, T. (2011). Evaluation the drivers of green supply chain management practices in uncertainty. Procedia-Social and Behavioral Sciences, 25, 384-397. https://doi.org/10.1016/j.sbspro.2012.02.049

Wyatt, D.P. (1994). Recycling and serviceability: The twin approach to securing sustainable construction. The Proceedings of First International Conference of CIB TG.

Xiao, X. (2006). Green supply chain management in the UK and China construction industry. Master of Science, University of East Anglia, Norwich.

Yang, L., Lam, J. C., \& Tsang, C.L. (2008). Energy performance of building envelopes in different climate zones in China. Applied Energy, 85(9), 800-817. https://doi.org/10.1016/j.apenergy.2007.11.002 
Yang, W., \& Zhang, Y. (2012). Research on factors of green purchasing practices of Chinese. Journal of business management and economics, 3(5), 222-231.

Ying-Liu, J., Pheng-Low, S., \& He, X. (2012). Green practices in the Chinese building industry: drivers and impediments. Journal of Technology Management in China, 7(1), 50-63. https://doi.org/10.1108/17468771211207349

Zhang, H.C., Kuo, T.C., Lu, H., \& Huang, S.H. (1997). Environmentally conscious design and manufacturing: a state-of-the-art survey. Journal of manufacturing systems, 16(5), 352. https://doi.org/10.1016/S0278-6125(97)88465-8

Zhang, X., Shen, L., \& Wu, Y. (2011). Green strategy for gaining competitive advantage in housing development: a China study. Journal of Cleaner Production, 19(2), 157-167. https://doi.org/10.1016/j.jclepro.2010.08.005

Zhu, A.Y., von Zedtwitz, M., Assimakopoulos, D., \& Fernandes, K. (2016). The impact of organizational culture on Concurrent Engineering, Design-for-Safety, and product safety performance. International Journal of Production Economics, 176(Supplement C), 69-81. https://doi.org/10.1016/j.ijpe.2016.03.007

Zhu, Q., \& Sarkis, J. (2004). Relationships between operational practices and performance among early adopters of green supply chain management practices in Chinese manufacturing enterprises. Journal of operations management, 22(3), 265-289. https://doi.org/10.1016/j.jom.2004.01.005

Zhu, Q., Sarkis, J., \& Lai, K.-H. (2008a). Confirmation of a measurement model for green supply chain management practices implementation. International Journal of Production Economics, 111(2), 261-273.

https://doi.org/10.1016/j.ijpe.2006.11.029

Zhu, Q., Sarkis, J., \& Lai, K.-H. (2008b). Green supply chain management implications for "closing the loop". Transportation Research Part E: Logistics and Transportation Review, 44(1), 1-18. https://doi.org/10.1016/j.tre.2006.06.003

Zhu, Q., Tian, Y., \& Sarkis, J. (2012). Diffusion of selected green supply chain management practices: an assessment of Chinese enterprises. Production Planning \& Control, 23(10-11), 837-850.

https://doi.org/10.1080/09537287.2011.642188

Journal of Industrial Engineering and Management, 2018 (www.jiem.org)

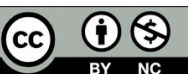

Article's contents are provided on an Attribution-Non Commercial 4.0 Creative commons International License. Readers are allowed to copy, distribute and communicate article's contents, provided the author's and Journal of Industrial Engineering and Management's names are included. It must not be used for commercial purposes. To see the complete license contents, please visit https://creativecommons.org/licenses/by-nc/4.0/. 